\title{
FURTHER EVIDENCE OF DISCRIMINATION \\ IN NEW CAR NEGOTIATIONS AND ESTIMATES OF ITS CAUSE
}

\author{
Ian Ayres*
}

\section{INTRODUCTION}

A 1991 test of new car dealerships in Chicago indicated that dealerships offered significantly lower prices to white male testers than to similarly situated black and-or female testers: white female testers were asked to pay $40 \%$ higher markups than white male testers; black male testers were asked to pay more than twice the markup of white male testers; and black female testers were asked to pay more than three times the markup of white male testers. ${ }^{1}$ This article extends the results of this initial test by presenting not only more authoritative evidence of discrimination but also a new quantitative method of identifying the causes of discrimination.

Although the results of the original study were based on 165 negotiations, the original article emphasized that:

[t] he most significant methodological weakness concerns the number of testers per tester type.... Only six testers were hired: one white female, one black female, one black male, and three white males. Thus, for example, the results demonstrating discrimination against black females are based on tests conducted by an individual black female (paired with one of three white males). ${ }^{2}$

This article presents the results of an expanded audit study that corrects for this weakness. In the expanded audits, 38 testers, including 5 black males, 7 black females, and 8 white females, negotiated for over 400 automobiles. The results are more authoritative than the prior test because there is a larger sample size and more testers in each race-gender category, and because the tests were conducted

* William K. Townsend Professor, Yale Law School. B.A. 1981, J.D. 1986, Yale; Ph.D. (Economics) 1988, MIT. - Ed. Peter Cramton, John Donohue, Owen Fiss, Michael Horvath, Mark Kelman, Peter Siegelman, Eric Talley and seminar participants at Stanford Law School, the American Law and Economics Asśociation annual meetings and the Stanford Center on Conflict and Negotiation provided helpful comments. Support from the American Bar Foundation is gratefully acknowledged.

1. Ian Ayres, Fair Driving: Gender and Race Discrimination in Retail Car Negotiations, 104 HARV. L. REv. 817, 819 (1991).

2. Id. at 826 . 
with enhanced controls to ensure further that testers were similar except for their race and gender.

The results of the expanded audit confirm the previous finding that dealers systematically offer lower prices to white males than to other tester types. But the more comprehensive data reveal a different ordering of discrimination than in the prior study: as in the original study, dealers offered all black testers significantly higher prices than white males, but unlike the original study, the black male testers were charged higher prices than the black female testers. ${ }^{3}$ This article examines whether this different gender ordering of discrimination for black testers provides insights about the causes of discrimination ${ }^{4}$ or whether it suggests weaknesses in the audit design. ${ }^{5}$

This article also uses a game-theoretic analysis of sellers' negotiation strategy to infer the causes of the sellers' demonstrated race and gender discrimination. At first blush, it seems difficult to use evidence of higher offers to distinguish between different possible causes of discrimination: for example, because either animus or statistical inference might cause a dealer to make a higher offer, it would seem impossible to infer from a higher offer whether the dealer was motivated by hatred or profits. This reasoning holds true if the dealer only makes a single offer to each buyer. It is possible, however, to infer more about the causes of discrimination when the dealer makes multiple offers. The dealer's choice of an initial offer, the size of concessions, and the speed of concessions will vary if the discrimination has different causes. For example, sellers might offer a higher initial price to black customers either if they believe that the black consumers are averse to bargaining or if the sellers have a particular desire to disadvantage black consumers. ${ }^{6}$ But game theory suggests that these two causes of discrimination will give rise to different concession rates: in particular, a desire to disadvantage blacks would cause sellers to hold out longer for a high price, implying a lower concession rate than if sellers offer high initial prices because they believe black consumers are

3. See infra notes 27-29 and accompanying text. White females continued to receive offers that were higher than the offers to white males, but lower than the offers to black males or females.

4. For example, the earlier finding that testers received the highest offers from salespeople of the same race and gender was not replicated in the subsequent study. See infra notes 27-29 and accompanying text.

5. Richard Epstein has recently suggested this possibility. Richard A. EpSTEIN, Forbid. DEN GROUND 51-54 (1993).

6. We refer to these two motivations respectively as "cost-based statistical discrimination" and "consequential animus." See infra notes 61-65 and accompanying text. 
averse to bargaining. ${ }^{7}$ Our evidence of the dealers' initial offers and willingness to make concessions can thus be used to distinguish among different causal theories.

Game-theoretic analysis of bargaining predicts that a seller's strategy will be a function of the seller's beliefs about certain variables, including the buyer's reservation price ${ }^{8}$ and the buyer's and seller's costs of bargaining. Although these variables in theory determine the buyer's and seller's negotiation strategies, ${ }^{9}$ to date no one has estimated the actual effect of these variables in real world negotiations. ${ }^{10}$ This article provides a first attempt at deriving numerical estimates of these structural parameters. ${ }^{11}$ Evidence about the sellers' initial offers, final offers, and the lengths of the negotiation is used to estimate crudely the sellers' beliefs about buyers' reservation prices, the buyers' costs of bargaining, and the sellers' costs of bargaining.

This process is repeated to estimate the sellers' beliefs with regard to each race-gender tester type. The article uses the evidence about sellers' beliefs to distinguish among four different causal theories of discrimination:

(1) Sellers may have higher costs per period negotiating with certain buyer types - "associational animus";

(2) Sellers may desire to disadvantage certain buyer types - "consequential animus";

(3) Certain buyer types may have higher per-period negotiating costs

- "cost-based statistical discrimination",12 and

(4) Certain buyer types may have higher reservation prices "revenue-based statistical discrimination."

7. See infra notes $61-62,82$ and accompanying text.

8. A buyer's reservation price is his or her willingness to pay. Dealers attempting to extract the maximum amount of revenue from each consumer will attempt to assess "the consumer's firm-specific reservation price - that is, how much the consumer is willing to pay for a car from a particular dealership." Ayres, supra note 1, at 844 . Dispute resolution theorists alternatively refer to a reservation price as a person's "BATNA," which stands for "best alternative to negotiated agreement." See Roger FISHER \& WILIIAM URY, GETTING to Yes 104-11 (Business Books 1991) (1981); Jennifer Gerarda Brown \& Ian Ayres, Economic Rationales for Mediation, 80 VA. L. Rev. 323, 331 \& nn.26-27 (1994).

9. See, eg., Anat R. Admati \& Motty Perry, Strategic Delay in Bargaining, 54 R. EcoN. STUD. 345 (1987); Peter C. Cramton, Dynamic Bargaining with Transaction Costs, 37 MGMT. Scr. 1221 (1991).

10. Bargaining experiments have explored how student subjects change their behavior as the costs of negotiation delay increase. See, e.g., Elizabeth Hoffman \& Mathew Spitzer, The Coase Theorem: Some Experimental Tests, 25 J.L. \& EcoN. 73 (1982).

11. Prior efforts to estimate the underlying parameters of game-theoretic models of bargaining have been constrained by the quality of the empirical data. See, e.g., Peter C. Cramton \& Joseph S. Tracy, Strikes and Holdouts in Wage Bargaining: Theory and Data, 82 AM. ECON. REv. 100 (1992).

12. As discussed infra at note 47 , this article uses a slightly different definition of "costbased" discrimination than the original article. 
Estimating the sellers' beliefs about different buyer types can thus "nest" these four causal tests of discrimination in a single parameterization that lets the sellers' own conduct reveal their motives. ${ }^{13}$

The estimates of the buyers' and sellers' cost of bargaining and of the buyers' reservation price are based on a number of extreme assumptions that are not only literally false but probably fail to capture important parts of reality. The estimates are at best a heuristic exercise to guide us imperfectly toward determining the causes of discrimination. But given that virtually no other quantitative evidence about the causes of discrimination in this or any other market exists ${ }^{14}$ and given the usefulness of estimating the basic determinants of negotiation strategies, these estimates of the sellers' beliefs may shed some additional light on a relatively dark corner of the civil rights landscape.

With these important caveats, this parameterization of the bargaining game suggests three primary conclusions:

- Sellers discriminate against different buyer types for different reasons. Cost-based inferences may explain part of sellers' discrimination against black females while consequential animus may explain part of sellers' discrimination against black males;

- The sellers' bargaining behavior is inconsistent with associational animus but supports - especially regarding black males - consequential animus as a partial cause of the sellers' discrimination; and

- The sellers' bargaining behavior is broadly consistent with revenuebased statistical inferences as a partial cause of the sellers' discrimination.

These conclusions are also generally consistent with ancillary evidence about the causes of discrimination. As suggested in the original study, revenue-based discrimination explains at least part of sellers' behavior. ${ }^{15}$ The game-theoretic parameterization, with all its limitations, however, suggests a less monolithic explanation.

The first Part describes the design of the expanded audit study and reports the evidence of race and gender discrimination. Part II then uses the game-theoretic analysis to distinguish potential causes of the discrimination. The conclusion steps back from the specific evidence of discrimination and its several causes to consider legal remedies and suggests that the types of discrimination uncovered in these audits could be reduced by encouraging dealers to switch to

13. A model can "nest" different hypotheses if forms of each hypothesis occur for distinct parameter values of the model.

14. But see John Yinger, Measuring Racial Discrimination with Fair Housing Audits: Caught in the Act?, 76 AM. ECON. REv. 881 (1986).

15. Ayres, supra note 1 , at $843-45,847-52$. 
no-haggle sales and that enhanced consumer protection laws might be successful in nudging the market toward a no-haggle equilibrium.

\section{Estimating the Extent of Discrimination}

\section{A. Describing the Audit Design}

The auditing method used to produce the data in this study largely paralleled the method used in the original study. ${ }^{16}$ The testers were trained to follow a uniform bargaining script, and then sent individually to negotiate the purchase of a new automobile at randomly selected Chicago-area dealerships. Two testers - one of whom was a white male - separately visited each dealership. Thirty-eight testers bargained for approximately 400 cars comprising 9 car models ${ }^{17}$ at 242 dealerships. ${ }^{18}$

Dealerships were selected randomly, testers were assigned to dealerships randomly, and the choice of which tester in the pair would first enter the dealership was made randomly. In most cases, the two testers visited the dealership within a few days of each other. Great pains were taken to assure that the testers projected a standardized appearance. ${ }^{19}$ The expanded audits also used two adat 822 .

16. For a complete description of the original audit methodology, see Ayres, supra note 1,

17. The nine models included a range from compacts to standard size cars, and included both imports and domestic makes. Human-subject review committees, seeking to protect the privacy of the dealers as human subjects in these tests, prevented us from disclosing the car models.

18. Because of discarded tests and scheduling difficulties 98 of the 404 observations are unpaired negotiations in which only one tester visited a particular dealership. Sample selection problems are always a concern in such situations. Chow tests on all four of the OLS equations reported infra in Table II cannot reject pooling the paired and unpaired observations, however, so there is little reason to believe that the unpaired audits are systematically different from the paired audits. See also Ian Ayres \& Peter Siegelman, Race and Gender Discrimination in Bargaining for a New Car, 85 AM. ECON. REv. 304 (1995) (finding similar results from analysis of paired data alone).

The test allowed dealers to systematically steer testers to cars with different options. As in the original study, there was no evidence of this behavior: the average cost of the cars bargained for did not vary significantly by tester type.

19. As in the original study, the testers' actual age, education, and attractiveness were similar and the testers were trained to project similar class characteristics:

1. Age: All testers were 24 to 28 years old.

2. Education: All testers had three or four years of college education.

3. Dress: All testers dressed similarly during the negotiations. Testers wore casual "yuppie" sportswear: the men wore polo or button-down shirts, slacks, and loafers; the women wore straight skirts, blouses, minimal make-up, and flats.

4. Economic Class: Testers volunteered that they could finance the car themselves.

5. Occupation: If asked by a salesperson, each tester said that he or she was a young urban professional (for example, a systems analyst for First Chicago Bank).

6. Address: If asked by the salesperson, each tester gave a fake name and an address for an upper-class, Chicago neighborhood (Streeterville).

7. Attractiveness: Applicants were subjectively ranked for average attractiveness. 
ditional procedures to insure uniformity among the testers. ${ }^{20}$ First, the testers drove to the dealerships in similar used rental cars of the same model and year. Using similar modes of transportation prevented the dealers from making inferences about the kind of car the tester drove or the way the tester reached the dealership. ${ }^{21}$ Second, unlike the original audits, the testers were not aware that the research was intended to test for race and gender discrimination. 22

The testers followed a uniform bargaining script designed to frame the bargaining in purely distributional terms. The script instructed the testers to focus quickly on a particular car $^{23}$ and to tell the dealers that they could provide their own financing for the car. At the beginning of the bargaining, testers waited for an offer from the dealer or, after five minutes, elicited a dealer offer. Once the dealer made an initial offer, the tester waited five minutes and responded with a counteroffer equal to our estimate of the dealer's marginal cost for the car. ${ }^{24}$

If the salesperson responded by lowering his or her offer, the test continued, with the tester's next counteroffer derived from the script in one of two ways. At some dealerships, the pairs of testers used a "split-the-difference" strategy - like that used by all of the testers in the original study - in which the tester's counteroffer split the difference between the dealer's offer and the tester's last offer. Thus, if a tester initially counteroffered $\$ 10,000$ and the salesperson responded with an offer of $\$ 12,000$, the tester's next response would be $\$ 11,000$. At other dealerships, the testers used a

\section{Ayres, supra note 1 , at 825 .}

20. Initially, some testers were instructed to volunteer that they would be moving to California in the coming month. This representation, suggested by Mitch Polinsky, sought to reduce dealers' inferences about repeat sales, referral sales, or repair service. However, dealers encountering two customers moving to California looking for the same car on the same day were more likely to voice a suspicion that the two consumers were not shopping independently. Because of the dealer expressions of suspicion, this Califomia representation was abandoned and the tests in which this representation was made were discarded. This example illustrates a general tension between increased controls and maintaining verisimilitude.

21. In the original study, all the testers parked their cars out of the dealership's sight and approached the dealership on foot. See Ayres, supra note 1, at 824 n.27. Some dealers remarked to testers that it was unusual, especially in the suburbs, for customers to walk onto a dealership lot.

22. In the original study, the testers knew the study's purpose, and it is possible that this knowledge affected their expectations or behavior. Id. at 824-25 n.27. In the larger study, the testers did not even know that another tester would be negotiating at each of the dealerships. The testers were told only that the research was investigating how dealers negotiate.

23. If they were shown more than one car of the type they were bargaining for, the testers were instructed to choose the car with the lowest sticker price.

24. Estimates of dealer cost were taken from Consumer Reports Auto Price Service and Edmund's $1989 \mathrm{New}$ Car Prices. As we discuss infra at note 47, making an initial offer at the dealer's cost reveals to the dealer that the tester is a fairly sophisticated buyer. 
"fixed-concession" strategy in which the testers' counteroffers were independent of the sellers' behavior. Testers began, as before, by making their first counteroffer at marginal cost. Regardless of how much the seller conceded, each of the tester's subsequent counteroffers increased her previous offer by $20 \%$ of the gross markup. ${ }^{25}$

Under either bargaining strategy, the tester continued to alternate offers with the dealer until the dealer either (1) attempted to accept a tester's offer, ${ }^{26}$ or (2) refused to bargain further. During the course of negotiations, testers jotted down each offer and counteroffer as well as options on the car and its sticker price. After leaving the dealership, each tester completed a survey describing the offers and counteroffers as well as ancillary details of the test - including, for example, the kinds of questions the dealers asked and the race and gender of the salesperson with whom they negotiated.

\section{B. Tests of Discrimination}

Table I reports regressions testing whether dealers treated testers differently. Because the testers were trained to follow an identical bargaining script, any statistically significant difference in the offers made to distinct race-gender types can be ascribed to disparate treatment by the dealers. In particular, the regressions - after controlling for the effects of several variables that varied across the audits ${ }^{27}$ - test whether the dealers' initial and final offers were higher to black and-or female testers than to white male testers.

25. That is, if the car had a sticker price of SP and the tester's last offer was LO, then the tester's next offer would be LO $+0.2 \times(S P-L O)$. Because the gross margin (SP - LO) decreases as the bargaining continues, the fixed-concession strategy produced smaller concessions in each subsequent round.

26. The testers did not purchase cars. If a salesperson attempted to accept a tester offer, the tester would end the test, saying "Thanks, but I need to think about this before I make up my mind." As a legal matter, no contracts were formed both because the testers were carefully trained not to sign any documents and thus were protected by the Statute of Frauds and because the testers' counteroffers merely invited the dealers to make additional offers "Would you sell me this car today for \$... ?" Ayres, supra note 1, at 824 n.25.

27. Besides three tester race and gender dummy variables WHITE FEMALE, BLACK MALE, and BLACK FEMALE - the regression attempted to discover what aspects of the bargaining caused dealers to demand a particular level of profit in their initial and final offers. In particular, the regression focused on the relationship between the profits the dealers would have made on their offers and the following variables:
SPLIT
$=1$, if tester used split-the-difference negotiating strategy, 0 , if fixed-concession strategy.
MODEL $_{j}=$ dummy variables for each different model type
$\mathrm{DAY}_{k} \quad=$ dummy variables for each day of the week
WEEK $_{1} \quad$ = dummy variables for each week of the month
TIME = number of days since start of testing
EXPERIENCE $=$ number of prior tests by this tester
FIRST $\quad=1$, if tester was the first in the pair to visit dealership, 
Table I shows that of all the tester types black males clearly fared the worst, paying an extra $\$ 962$ over white males on initial offers and $\$ 1132$ on final offers, after controlling for exogenous variables. These coefficients are highly statistically significant -6 to 9 times their standard errors. Dealers' initial and final offers to black females were roughly $\$ 470$ and $\$ 446$, about $4 \%$, higher than to white males. These coefficients are again highly significant in all the regressions. The disparate treatment of white females, in comparison, is less pronounced and statistically less significant. Dealers' initial and final offers to white females were roughly $\$ 200$ more than to white males, about a $2 \%$ additional markup - a difference, however, that is not statistically significant at the 5 percent level.

The current study confirms the original study's findings that offers to black males and black females are significantly higher than those made to white males. The ordering of discrimination, however, changed: while in the initial study the final offers to black females were $\$ 500$ higher than the final offers to black males, ${ }^{28}$ in the current study, as seen in Table I, black males received offers that were $\$ 686$ higher than those black females received. This changed ordering of discrimination suggests that individual charac-

\footnotetext{
0 , otherwise

UNPAIRED $=0$ if test was part of a paired audit, 1 if test was an unpaired observation.

The regression equation took the following form:

OFFER $=$ CONSTANT $+\Sigma_{i} \beta_{l}($ TESTER RACE/GENDER TYPE $)+\Sigma_{j} \mathrm{r}_{j} M O D E L_{j}+$

$\Sigma_{k} \delta_{k} D A Y_{k}+\Sigma_{l} \eta_{l} W E E K_{l}+\theta T I M E+v S P L I T+\lambda E X P E R I E N C E+\mu F I R S T+$

$v U N P A I R E D+\varepsilon$

where epsilon is an error term that is assumed to be independent and identically distributed.

Although a thorough review of econometric theory is beyond the scope of this article, a few concepts may be of use to the reader. The ordinary least square regression technique estimates the CONSTANT and the greek-letter coefficients, $\beta, \tau$, and so on in the regression equation - except for the error term. A "dummy variable" resembles an on-off switch assuming values of 0 or 1 . By assigning dummy variables to all but one category, we can compare differences between any two categories. Thus for the group of four mutually exclusive and exhaustive tester race-gender types, we assign a dummy variable to three of these four categories, and the regression provides us with the estimated coefficients for each variable; white men form the benchmark omitted category. The estimated dummy coefficients represent the amount by which membership in the associated category increases or decreases the dependent variable as compared to the benchmark category. See Ian Ayres \& Joel Waldfogel, A Market Test for Race Discrimination in Bail Setting, 46 STAN. L. REv. 987, 1009 n.84 (1994). For example in Table I, the $\$ 962$ coefficient associated with the BLACK MALE dummy variable suggests that the dealer profit on initial offers made to black male testers was $\$ 962$ higher than the profit on initial offers made to white male testers - the omitted benchmark category.
}

28. The average dealer profits for final offers made to different classes of testers were:

$\begin{array}{lr}\text { White Male } & \$ 362 \\ \text { White Female } & \$ 504 \\ \text { Black Male } & \$ 783 \\ \text { Black Female } & \$ 1,283\end{array}$


teristics of testers may have biased the results of the initial study. ${ }^{29}$ Therefore, in the current study, we tested for the presence of individual tester effects by using what econometricians call a "fixedeffects" regression specification. ${ }^{30}$ Using this more sophisticated specification, ${ }^{31}$ we found no evidence that any individual testers encountered idiosyncratic treatment - that is, treatment that differed from the treatment of other testers of the same race and gender. Even after controlling for potential individual effects, we found race and gender effects of the same size and statistical significance as in Table I. ${ }^{32}$

The regressions in Table I also tested the success of several procedural controls: for example, we expected the coefficients on the TESTER EXPERIENCE, FIRST, and UNPAIRED variables not to be statistically different from zero. ${ }^{33}$ The table shows that none of these coefficients were significant at the traditional 5 percent level and that additional tester experience added a trivial amount - $\$ 3.41$ - to the dealer's final offer. But the size of the FIRST coefficient in the final profit regression is troubling even though not statistically significant: it suggests that a dealer's final offer to the first tester in a pair was $\$ 138$ higher than to the second tester. This result might mean that some dealers realized a test was being conducted and artificially lowered the offer to the second testers. ${ }^{34}$

29. Because there was only one black male tester and only one black female tester in the original study, any systematic deviations by these testers from the script could have biased the test results. As noted in the original study: "The black male tester in the initial experiment, for example, was himself a former car salesperson and is currently a law student. It is possible that the lower offers he received in the initial experiment were by-products of his overly aggressive deviations from the script." Ayres, supra note 1, at 828 n.36. This explanation for the ordering in the earlier study, however, is not completely satisfying. In the current larger study the black female testers experienced much less discrimination than the single black female in the initial study. For example, the final offer differential with white males decreased more than $\$ 800$. Unlike my expectation for the black male in the initial study, I did not have any reason to expect that the black female tester in the initial study would be less aggressive than the subsequent black female testers.

30. See, e.g., William E. Griffiths et al., Learning and Practicing Econometrics 456-57 (1993).

31. For a discussion of this specification and the explicit results of the regression, see Ayres \& Siegelman, supra note 18, at 307-10.

32. See id. at 311-12.

33. If testers were faithfully following the script, testers who had previously completed more tests would not be treated differently. If the testers were successful at concealing the auditing, we would not expect the first tester to receive systematically different treatment than the second tester bargaining at the same dealership. Finally, if the unpaired audits were representative of the larger sample, we would not expect systematically different results from these tests.

34. Manufacturers, rival dealers, and U.S. Census officials at times audit dealerships to determine the real cost of purchasing a new car. Telephone Interview with Margerie Yonsura, Wordsmith Relations (Sept. 1, 1992). Altematively, the dealer may have lowered its offer after failing to sell to the initial tester. 
Table I: Regressions Evaluating EFfects of Testers'

RACE-GENDER TyPE AND CONTROL VARIABLES

ON DEALERs' InItIal AND Final Profits ${ }^{a}$

( $N=404 ; \mathrm{t}$-statistics in parentheses)

Initial \$ Profit

Final \$ Profit

\begin{tabular}{lcc}
\hline CONSTANT & $724.61^{*}$ & $417.52^{*}$ \\
& $(7.23)$ & $(6.62)$ \\
\hline Tester Race-Gender & & \\
WHITTE FEMALE & 209.62 & 215.69 \\
& $(1.54)$ & $(1.85)$ \\
BLACK MALE & $962.32^{*}$ & $1132.59^{*}$ \\
& $(6.75)$ & $(9.28)$ \\
BLACK FEMALE & $470.05^{*}$ & $446.30^{*}$ \\
& $(3.90)$ & $(4.32)$ \\
\hline Control Variables & & \\
SPLIT $^{b}$ & -240.19 & -262.59 \\
& $(-1.55)$ & $(-1.97)$ \\
TESTER EXPERIENCE & 4.76 & 3.41 \\
& $(0.66)$ & $(0.55)$ \\
FIRST & 88.23 & 138.48 \\
& $(0.91)$ & $(1.67)$ \\
UNPAIRED $^{\mathrm{e}}$ & -100.62 & -161.02 \\
& $(-1.00)$ & $(1.87)$ \\
\hline Summary Statistics $_{\text {ADJ-R }}^{2}$ & & \\
SSR $^{2} 0^{-3}$ & 0.27 & 0.33 \\
\hline
\end{tabular}

* Significantly different from zero at the 5 percent level.

a Other variables were included in the regression but are not shown to save space: model dummies, TIME (number of days since start of testing), day-of-week dummies, and week-ofmonth dummies. None of the coefficients on these unreported temporal variables were large or statistically significant.

$b 1$ if tester used split-the-difference negotiating strategy, 0 if fixed concession.

c Number of prior tests by this tester.

d 1 if tester was the first in the pair to visit this dealership, 0 otherwise.

- 0 if test was part of a paired audit, 1 if test was an unpaired observation.

We also expected that the tester's use of a split-the-difference strategy or a fixed-concession strategy would not affect the dealer's initial offer - for the simple reason that the tester elicited the dealer's initial offer before the tester began implementing either one of these counteroffer strategies. The SPLIT coefficient was un-

We were also concerned that the dealers' final offers on the unpaired bargaining sessions were $\$ 161$ lower than the final offers on bargaining sessions that were paired. This finding suggests that the dealership conditions that caused one of the tests to fail may have affected the results of the other, now unpaired, tester who was included in the regression sample. To control for this possible fiaw, we reran the regression using only the paired data and found that again the amount and significance of discrimination was not affected. 
expectedly negative, indicating that dealers' initial offers to testers using the split the difference strategy were $\$ 240$ less than the initial offers to testers using a fixed-concession strategy - but again this difference was not statistically significant.

The data also confirm that the initial study's finding that discrimination was not merely an artifact of the split-the-difference negotiation strategy that was used exclusively in the initial study. ${ }^{35}$ The dealers continued to discriminate even when the testers adopted a fixed-concession strategy. ${ }^{36}$ Table $I$ in fact suggests that the split-the-difference strategy might be the more effective strategy because it led to dealer offers that were $\$ 262$ lower than the fixedconcession strategy, even though this result was not quite statistically significant at the 5 percent level. ${ }^{37}$

In short, the regressions report strong evidence of disparate racial treatment. ${ }^{38}$ By following the audit script, the testers projected similar personal characteristics except for their race and gender, and all the tests of procedural irregularity were, as expected, statistically insignificant. ${ }^{39}$ Although, in contrast to the earlier study black men were discriminated against more than black women, there was a consistent pattern of racial discrimination, with white male testers receiving substantially lower offers than either type of black tester. Indeed, the initial offer white male testers received was lower than the final offer $43.5 \%$ of nonwhite males received. 40 That is, without any negotiating at all $43 \%$ of white males obtained

35. When testers' counteroffers split the difference, discrimination in early rounds may force dealers' final offers to be discriminatory as well. For example, if the dealer's second offer to a black male includes a $\$ 1000$ profit while the dealer's offer to a white male includes only a $\$ 400$ profit, then any subsequent bargaining will reflect discrimination because under a split-the-difference strategy the black male tester will counter with a price based on a $\$ 500$ profit that is higher than the dealer's earlier $\$ 400$ profit offer to the white male.

36. Separate regressions found no difference in the amount of discrimination for the fixed-concession negotiations. See supra note 25 (describing the fixed-concession strategy).

37. A 5 percent level of significance would require a t-statistic with an absolute value greater than 1.98. As shown in Table I, the coefficient estimate for the SPLIT variable has a t-statistic of 1.97 and so is almost significant at the standard 5 percent level.

38. For an alternative interpretation of these results, see EPSTEIN, supra note 5, at 51-54. But see also Ian Ayres, Alternative Grounds: Epstein's Discrimination Analysis in Other Market Settings, 31 SAN Drego L. Rev. 67 (1994) (responding to these criticisms).

39. However, as discussed in the text the size of some of these insignificant coefficients gives us some residual concern about the effect of unpaired testers on final profits, first testers on final profits, and using the split-the difference strategy on initial profits. See supra notes 34-35 and accompanying text.

40. See Ayres \& Siegelman, supra note 18, at 313. 
a better offer than their counterparts achieved after bargaining for an average of forty-five minutes. ${ }^{41}$

\section{Estimating the Causes of Discrimination}

The regression results establish the existence of discrimination but not its cause. This Part uses a game-theoretic model of bargaining to explore empirically the reasons why dealers chose to treat black and-or female consumers differently than white males. It is particularly difficult to distinguish among competing causal hypotheses without an explicit model of how bigotry or cupidity might influence sellers' bargaining behavior. For example, though both animus and profit-maximizing statistical theories of discrimination might cause dealers to offer black testers higher initial prices, it is unclear what either of these theories implies about the size or rate of the dealers' concessions when buyers and sellers take time to haggle.

We show that different explanations of discrimination cause the dealer's choice of an initial offer, the size of concessions, and the speed of concessions, to vary. For example, sellers might offer a higher initial price to a black customer either if they believe that black consumers are averse to bargaining or if the sellers have a particular desire to disadvantage black consumers. But game theory suggests that these two causes of discrimination will give rise to different concession rates: in particular, a desire to disadvantage blacks will cause sellers to hold out longer for a high price, implying a lower concession rate than a belief that black consumers are averse to bargaining. ${ }^{42}$ Our evidence of the dealers' initial offers and willingness to make concessions can thus be used to distinguish among competing causal theories. To empirically identify the dealers' motive for discrimination, therefore, we derive a bargaining model that allows us to treat different causes of discrimination as special cases of a single bargaining game. For example, in this model certain parameter values produce a pure animus-based form of discrimination while other parameter values give rise to a pure profit-maximizing-based form of discrimination. We then use the

41. In tests in which white male testers received the lower final offer, the offers averaged $\$ 897$ less than their counterparts'; when nonwhite males received lower final offers, their offers beat the white males' offers by only $\$ 167$. Id. at 312-13.

42. See infra at notes $61-62,82$ and accompanying text. 
results of our audits to infer which causal theories best fit the data. ${ }^{43}$

\section{A. A Model of Animus and Statistical Discrimination in Bargaining}

We begin by developing a model of bargaining that will allow us to nest competing theories of animus and statistical discrimination. ${ }^{44}$ To reproduce the scripted bargaining procedure used in collecting the data, the buyer and seller in the model make alternating offers, beginning with an offer from the seller. The model also conforms to the data in that the seller can choose how long to delay before making an offer. ${ }^{45}$ The buyer and seller each incur costs per unit of time spent bargaining, equal to $c_{b}$ and $c_{s}$ and these costs are assumed to be common knowledge. 46

The seller's reservation price is assumed to be its marginal cost, and this amount is common knowledge. ${ }^{47}$ For expositional convenience, the seller's reservation price is normalized to zero, which means that in looking at our results, the seller's profit equals the

43. In "audit" tests of disparate treatment, pairs of similarly situated testers typically audit a number of establishments in a market to see if decisionmakers discriminate on the basis of race or gender. Systematic audits of race and gender discrimination have been conducted in a variety of other markets. See, e.g., Michael Fix \& RaYMond J. StruYr, Clear and Convincting Evidence: Measuring Discrimination In AMERICA (1993) (housing and employment audits); Yinger, supra note 14 (housing audit).

44. The model is based on a bargaining game designed by Peter Cramton. See Cramton, supra note 9.

45. Cramton's original model also allowed the buyer to choose how long to delay before making an offer. Even though testers following the script made their offers five minutes after a new dealer offer, the script's timing restriction does not affect the seller's equilibrium strategy because the model predicts that the seller's strategy will be independent of the buyer's bargaining strategy. See infra note 54.

46. The model also assumes a second type of transaction cost in that all traders discount future payoffs at a common rate, $r$. Alternatively, $r$ can be interpreted as the probability, per unit of time, that the negotiations will exogenously break down. The importance of $r$ as an underlying determinant of the bargaining equilibrium is discussed infra at notes 78-79 and accompanying text.

47. Both of these assumptions are reasonable: a seller's marginal cost is often a good proxy for its reservation price, see Ian Ayres \& Clayton Miller, "I'll Sell It to You at Cost:" Legal Methods to Promote Retail Markup Disclosure, 84 Nw. U. L. REv. 1047 (1990), and the testers quickly indicated that the sellers' cost was common knowledge by setting their first counteroffer equal to this cost. See supra note 24 and accompanying text.

The model also assumes that the dealer's marginal cost of selling a car is the same for all tester race-gender types. This is reasonable because the testers' script was explicitly structured to eliminate cost-based differences among the testers. For example, the testers volunteered that they did not need financing. See Ayres, supra note 1, at 846 . The original study used the term "cost-based discrimination" to refer to the possibility that dealers would offer different prices if they believed there were different costs of selling to specific tester types. Here, the term is used to refer to the possibility that dealers would offer different prices if they believed that certain tester types had higher per period costs of bargaining. 
price, and the gains from trade are equal to the buyer's reservation price.

The buyer, however, is assumed to have private information about her reservation price, although the distribution of buyers' reservation prices is common knowledge. To solve the model, we assume that the buyers' reservation prices are distributed uniformly between 0 and some maximum value, $h .48$

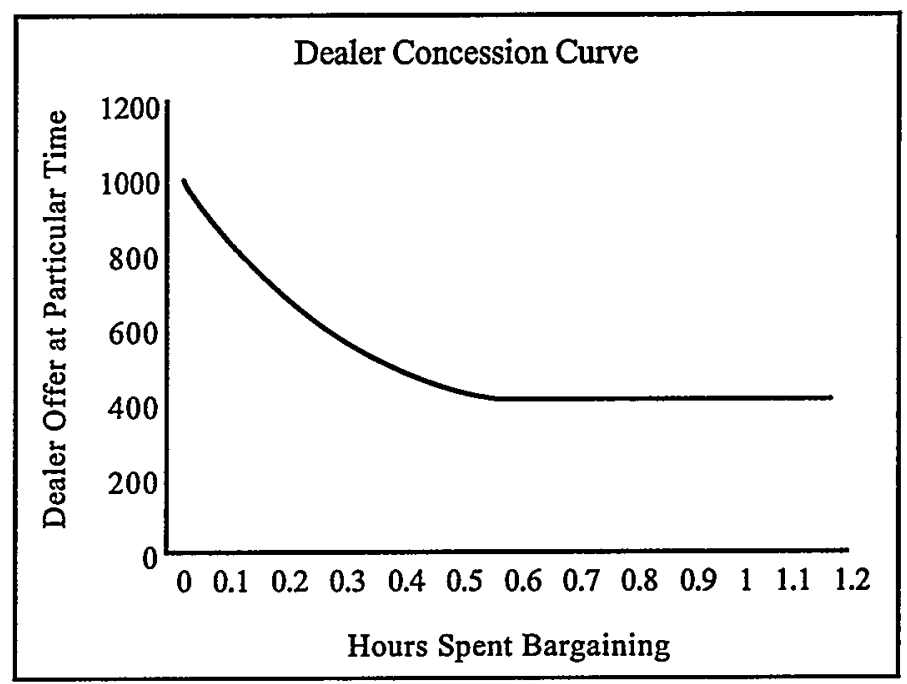

Figure 1: Dealer Concession Curve

These assumptions give rise to a "signalling" equilibrium because the buyer's option to delay allows buyers with low reservation prices to signal this fact by their willingness to delay. ${ }^{49}$ The dealer's equilibrium strategy is contingent upon three underlying parameters: the buyer's and seller's per period cost of bargaining and the buyer's maximum reservation price $-c_{s}, c_{b}$, and $h$. Given particular values of these parameters, the Appendix shows that a simple concession curve summarizes a seller's equilibrium strategy: for example, Figure 1 depicts a concession curve - when $c_{s}=c_{b}=\$ 100 /$

48. The assumption that the distribution of buyers' reservation prices has a lower support of 0 is not restrictive. As shown infra note 54, the sellers' optimal bargaining strategy is independent of this lower support - so at least in the case of a uniform distribution, rational buyers only need to infer the location of the upper support.

49. Because the gains from trade are discounted - by a common discount rate, $r-$ buyers with low reservation prices have lower costs of delay and hence can use delay as a credible signal. Admati \& Perry, supra note 9. Unlike screening models, this model has the attractive feature that the equilibrium does not depend critically on a minimum time between offers. 
hour, and $h=3000.50$ The concession curve shows the offer that the seller is willing to make at any particular time. A seller's equilibrium concession strategy has the following characteristics:

The seller starts by making the initial offer - depicted at time 0 on the concession curve; 51 if the buyer makes a counter offer on or above the concession curve, the seller accepts; 52 if the buyer makes a counter offer below the curve, the seller rejects and offers the price on the concession curve for the elapsed amount of time..$^{53}$

The model predicts that sellers will make a series of decreasing offers, but that at some point rationally will refuse to make any further concessions. ${ }^{54}$

If dealers' beliefs about the underlying parameters $-c_{s}, c_{b}$, and $h$ - are different for specific tester types, the model predicts that dealers will use different concession curves when bargaining with these different tester types. Thus, if a dealer experiences a higher cost of bargaining with a particular type of buyer, or believes that a particular type of buyer has a higher willingness to pay, or has higher costs of bargaining, the model predicts how these differences will affect the dealer's behavior. The details of the model are worked out in the Appendix. 55

The next Part shows how dealers' beliefs about these three variables correspond to traditional causal theories of discrimination.

50. The example also assumes that the discount rate for both parties is .5 . See infra notes 78-79 and accompanying text.

51. In Figure 1 , the seller's initial offer is $\$ 1000$.

52. For example in Figure 1, if the buyer offers $\$ 800$ after one-quarter of an hour, the seller would accept.

53. For example in Figure 1, if the buyer offers $\$ 600$ after one-quarter of an hour, the seller would reject the offer and immediately offer $\$ 789$. The model's prediction that sellers would immediately counter any buyer offer lower than the concession curve was somewhat contradicted by tester experience, however, as testers reported that sellers would at times delay before making subsequent offers.

54. As shown in Figure 1, after .6 hours, the seller refuses to make any further concessions below $\$ 400$. Sellers know that buyers with a reservation price below some critical value cannot credibly signal their valuation because the transaction costs of delay are greater than the buyer's expected gains from trade. Sellers infer that these low valuers will not find it worthwhile to begin bargaining, and sellers consequently choose not to make offers to buyers with these low valuations. See infra app.

The model also predicts that a seller's offers will be independent of the buyer's previous counteroffers: for example, in Figure 1 the seller's strategy after one-quarter of an hour is to offer to sell for $\$ 725$ - regardless of whether the buyer's last counteroffer was $\$ 150$ or $\$ 700$. This prediction of independence finds at least weak support in the data - because as reported earlier, sellers' final offers when testers used a fixed-concession strategy were not significantly different from sellers' final offers when testers used a split-the-difference strategy. See supra note 37 and accompanying text. As stressed above, however, the difference in the offers was unexpectedly high and almost achieved 5 percent significance. See supra note 37 and accompanying text.

55. See infra app. 
We then use evidence of the dealers' actual concession curves to infer which of the causal theories best explains the data.

\section{B. Causal Theories of Discrimination in Bargaining}

The bargaining model we derived can accommodate four competing explanations as to why dealers would offer higher prices to a disfavored group than to white males:

(1) Sellers may have higher costs of bargaining with a disfavored group - "associational animus," reflected in higher values of $c_{s} ;$;

(2) Sellers may desire to disadvantage a disfavored group - "consequential animus," reflected in lower net values of $c_{s}$;

(3) Sellers may believe that a disfavored group has higher costs of bargaining - "cost-based" discrimination, reflected in higher values of $c_{b} ;$ and

(4) Sellers may believe that a disfavored group has higher reservation prices - "revenue-based" discrimination, reflected in higher $h$.

First, consider associational animus. In the employment context, Gary Becker showed that if a bigoted employer dislikes spending time with members of a particular group, the employer may offer members of that group a lower wage to compensate the employer for this associational animus.57 In our model a seller's dislike of spending time with a particular group, associational animus, can be naturally captured by an increase in the seller's costs per period $\left(c_{s}\right)$ of associating, when negotiating with testers from the disfavored group.

In our bargaining model, "associational animus" yields a startlingly perverse result: black consumers can benefit from the presence of bigotry. One of the robust ${ }^{58}$ results of bargaining theory is that higher bargaining costs tend to reduce one's bargaining power. ${ }^{59}$ Thus, higher per period costs of negotiating with black consumers should lower sellers' bargaining power and induce them to make lower offers to black buyers. ${ }^{60}$ Thus, even before we formally estimate the model, theory suggests that associational animus

56. This article also examines the possibility that different discount rates might give rise to disparate treatment. See infra note 102 and accompanying text.

57. Gary S. Becker, The Economics of Discrimination (2d ed. 1971).

58. A "robust" result is one that remains unchanged as inconsequential assumptions vary.

59. See Martin J. Osborne \& ARIel Rubinstein, A Course In Game Theory 117-31 (1994).

60. Sufficiently large associational costs could reverse the market power story by causing a seller to terminate the negotiations if the buyer does not accept what is in effect a take-itor-leave-it initial offer. See Cramton, supra note 9, at 1222-23. However, given that the dealers were willing to spend a substantial amount of time bargaining with all testers, see infra tbl. II, and dealers bargained longer with black men then with white men, see infra tbl. II, it is unlikely that this extreme form of associational animus could explain our results. 
against black customers will not be able to explain why, in a bargaining context, dealers offered black testers higher prices.

The perverse result that seller bigotry might benefit blacks suggests that allowing animus to take only the form of an associational tax (a higher $c_{s}$ ) does not account for all possible forms of bigotry. For example, bigoted sellers might alternatively enjoy extracting a high profit more from black or female customers than from white males. The Appendix shows that disproportionately valuing profits from disfavored groups has the effect of reducing the seller's effective, per-period cost of bargaining. ${ }^{61}$ We refer to this type of discriminatory motive as "consequential animus" because the seller dislikes the consequence of contracting with disfavored groups on equal terms. ${ }^{62}$ Sellers motivated by consequential animus act as if they had lower per period costs of bargaining: they are willing to bargain longer for a high price because they attach a higher value to extracting profits at the expense of a disfavored group. Unlike associational animus, consequential animus - by reducing the seller's effective costs of bargaining - enhances a seller's bargaining power and is compatible with blacks and-or women receiving higher offers than white males.

The model can also capture two types of "statistical discrimination" based on sellers' inferences about a group's cost of bargaining or its willingness to pay. ${ }^{63}$ Statistical discrimination is caused not by

61. For example, a seller's payoff might increase by $\alpha>1$ for each additional dollar secured in negotiations with a disfavored consumer group. This form of consequential animus has the effect of lowering the seller's effective cost of bargaining, so that $c_{s}^{\prime}=c_{s} / \alpha$. See infra app.

62. Consequential animus may take many other forms as well. For example, if sellers enjoy seeing blacks and women expend time bargaining, this form of animus would also have the effect of decreasing sellers' net costs of bargaining with these groups. At a more subtle level, the sellers' motive may not be to disadvantage other groups, but to advantage their own group. Richard McAdams has recently explored the possibility that relative group preferences might provide a more compelling explanation of many types of discrimination. Richard H. McAdams, Cooperation and Conflict: The Economics of Group Status Production and Race Discrimination, 108 HARV. L. REv. 1003 (1995); see also John J. Donohue, III, Prohibiting Sex Discrimination In the Workplace: An Economic Perspective, 56 U. CHI. L. REv. 1337 (1989). Although the bargaining model analyzed in the text begins with individual preference as the foundational cause of discrimination, McAdams's work explores the social underpinnings of these preferences.

63. One car salesman tumed consumer advocate described the general tendency of dealers to make statistical inferences based on gender: "[S]alesmen ... . categorize people into 'typical' buyer categories. During my time as a salesman I termed the most common of these the 'typically uninformed buyer' .... [In addition to their lack of information, these] buyers tended to display other common weaknesses. As a rule they were indecisive, wary, impulsive and, as a result, were easy to mislead. Now take a guess as to which gender of the species placed at the top of this 'typically easy to mislead' category? You guessed it - women." Darrell Parrish, The Car Buyer's Art. How to Beat the Salesman at His OWN GAME 3 (1989). 
sellers' animus, but rather by their use of observable variables such as race or gender to maximize profits. ${ }^{64}$ "Cost-based" discrimination could occur, for example, if a seller believes that a disfavored group is on average more averse to bargaining. Bargaining aversion or impatience might cause buyers to act as if they had higher bargaining costs. The sellers' statistical inference about a group's cost of bargaining might cause profit-maximizing sellers to quote higher prices to all members of this group because sellers would believe that members of this group on average have less bargaining power. The model captures the possibility of "cost based" discrimination by allowing sellers to form different beliefs about the bargaining costs $\left(c_{b}\right)$ of specific tester race-gender types. ${ }^{65}$

Finally, we can use the model to examine "revenue based" statistical inferences founded on perceived differences in the distribution of reservation prices among consumer groups. ${ }^{66}$ If sellers believe that blacks or women have different distributions of reservation prices than white males - for example, distributions with higher means or greater variances, this could lead dealers to offer higher prices to members of these groups.

Profit-maximizing sellers might use race or gender to make inferences not only about the expected revenues, but also about the expected costs of selling a car to a particular buyer including, for example, the expected costs of default on car loans. The script, however, attempted to eliminate this type of statistical discrimination by having all testers volunteer early in the negotiations that they were providing their own financing, so the dealership bore no default risk. Even though all testers volunteered that they did not need financing, dealers might disparately assess the credibility of this information depending on the gender and race of the tester. If statistically valid, this inference could form the basis for cost-based statistical discrimination. Profit-maximizing dealers might also make inferences about the profits from ancillary sales, so dealers' inferences about the likelihood of repeat purchases, referrals, or repair service could also cause statistical discrimination. To dampen the importance of such inferences, we initially had testers volunteer to salespeople that they were moving out of the state within a month. Having more than one tester make this representation at a single dealership, however, increased the likelihood that dealers would suspect a test, and so we discontinued it. See supra n.20.

64. Edmund S. Phelps, The Statistical Theory of Racism and Sexism, 62 Am. Econ. Rev. 659 (1972).

65. Within the precise confines of the model, the dealers' inferences about tester cost are not statistical in the typical sense. The model assumes that the testers' cost of bargaining $\left(c_{b}\right)$ is commonly known by both the tester and the dealer. Normally, statistical discrimination is modeled as a process whereby a decisionmaker uses gender or some other observable characteristic as a proxy for some unknown characteristic. See Phelps, supra note 64. But a belief that blacks have higher bargaining costs based on common knowledge would induce dealers to charge blacks higher prices just as a belief based on statistical inference would.

66. In the real world, statistical discrimination might be based on variables other than buyers' reservation prices. For example, unlike this model, buyers' bargaining costs are typically not known to sellers; sellers could thus use race or gender to make inferences about the costs of negotiations for different buyer types. Or, in models with search costs, sellers could use race or gender to infer buyers' search costs. In this model, buyers' reservation prices are the key variable that is unknown to sellers, and are thus the focus of statistical discrimination. 
The bargaining model used in the current study formalizes the assertion in the original article that revenue-based discrimination will often become a "search for suckers":

Anecdotal evidence suggests that at some dealerships up to fifty percent of the profits can be earned on just ten percent of the sales.... From a dealer's perspective, bargaining for cars is a "search for suckers" - a search for consumers who are willing to pay a high markup....

... In their quest to locate high-markup buyers, dealers are not guided by the amount that the average black woman is willing to pay. Rather, they focus on the proportion of black women who are willing to pay close to the sticker price. 67

The model starkly replicates this result because profit-maximizing sellers do not care about a group's average willingness to pay; rather, revenue-based discrimination turns solely on the seller's belief about the maximum amount any given group member would be willing to pay. ${ }^{68}$ The dealers' exclusive interest in estimating the "upper tail" of the buyer's willingness-to-pay distribution is an artifact of the uniform distribution assumption. However, the intuition that dealers' behavior will be more attuned to their beliefs about high-markup buyers rather than the average buyer still holds true under less restrictive assumptions. ${ }^{69}$ Therefore, even if blacks have a lower average willingness to pay than whites, profit-maximizing sellers might nevertheless make higher offers to blacks - as long as a sufficient number of black consumers are willing to pay an especially high markup.

This section has shown that the traditional game-theoretic determinants of bargaining behavior - that is, the buyer's and seller's costs of bargaining and inferences about the buyer's willingness to pay - can capture four different explanations of discrimination. On theoretical grounds, we have been able to reject "associational animus" as a plausible explanation for higher prices encountered by

67. Ayres, supra note 1 , at $854-55$ (citations omitted). The original article emphasized that the term "sucker" should not be taken to imply that high-markup buyers are irrational or uninformed because high search costs or a high aversion to bargain could make it rational to pay a high markup. Id. at $854 \mathrm{n} .109$.

68. Notice that the lower bound of the support of buyers' reservation prices, $l$, does not appear in the seller's first order condition, equation (3). More generally, the seller's strategy does not depend on $l_{\mathrm{i}}$ unless $l_{\mathrm{i}}$ is so high that the seller finds it optimal to make an initial offer that is acceptable to all type $i$ buyers. See Cramton, supra note 9. This did not occur in our data.

69. Even under general assumptions about distributions, a linear mean-preserving spread of buyers' reservation prices will shift a seller's offers upward for any given period of delay. Cramton \& Tracy, supra note 11. 
minority and-or female testers. The next section empirically evaluates the remaining three hypotheses.

Although the next section's estimates of the model's parameter values are an important first step in quantifying evidence of the causes of discrimination, our simple bargaining model cannot capture a number of powerful and more foundational explanations for discrimination. For example, the model cannot distinguish between rational statistical inference and irrational stereotyping, or identify the cause of the irrationality. ${ }^{70}$ As stressed in the original article: "it may prove impossible to parse out the various elements of animus and rational inferences from irrational stereotypes. No single causal theory may be adequate to explain discrimination against both blacks and women."71 With these caveats, the next section explores whether car dealers' disparate racial and gender treatment of consumers flows from different causes.

\section{Estimating the Parameters of the Model}

This section uses data on the sellers' actual concessions to estimate which seller beliefs would give rise to the measured bargaining behavior. We have shown how in theory the model predicts that three underlying parameters $\left(c_{s}, c_{b}\right.$, and $\left.h\right)$ will determine how sellers bargain. Now we work backward, using evidence of how sellers bargained with particular tester types to infer the underlying parameters that would be consistent with the sellers' bargaining behavior.

In particular, we calculated three measures of seller behavior when bargaining with each of the four tester types: the sellers' average initial offer $\left(p_{I}\right)$, the sellers' average final offer $\left(p_{F}\right)$, and average time spent bargaining $\left(\Delta_{F}\right){ }^{72}$ These averages, shown in section A of Table II give crude information about the shape of sellers' concessions curves when bargaining with different tester types.

70. The model can similarly capture whether dealers bargain as if they disproportionately enjoy disadvantaging minority buyers, but estimates of the sellers' bargaining cost cannot begin to tell us why sellers have such preferences. In part, this is because the model proceeds from an atomistic conception of dealers and dealer behavior: social influences on preferences are taken as exogenous. See McAdams, supra note 62; Anthony D. Taibi, Banking, Finance, and Community Economic Empowerment: Structural Economic Theory, Procedural Civil Rights, and Substantive Racial Justice, 107 HaRv. L. REv. 1463 (1994) (criticizing incompleteness of economic theories of discrimination).

71. Ayres, supra note 1 , at 852 .

72. The average final offer and the time spent bargaining were calculated using only those test sessions that ended with the seller's refusal to bargain further because in tests ending with attempted acceptances, the seller's attempted acceptance might have occurred at a point above the concession function. Moreover, the fact that negotiations ended with sellers refusing to bargain further allows us to identify buyer costs from equation (4), infra app. 
We can use these three observations about a seller's concession curve to estimate the seller's beliefs about the three parameters of interest: the sellers' and buyers' bargaining costs $\left(c_{s}\right.$ and $\left.c_{b}\right)$ and the upper bound of buyers' reservation prices $(h) .{ }^{73}$ This inferential process would be an interesting exercise in empirical game-theory if it were done once simply to evaluate the general determinants of seller behavior. But as we have shown, by repeating the process with regard to each buyer race-gender type, we can also evaluate alternative causal theories of discrimination. Our estimates of $c_{s}, c_{b}$, and $h$ are shown in part B of Table II and Figures 2-4 for each of the different buyer groups.

The estimates in Table II stand on a much weaker statistical footing than the estimates in Table I. The estimation method is extremely crude: in theory, all of the points on the sellers' concession curve could be used to identify the sellers' beliefs, but the estimation in Table II uses only three pieces of information about the curve, and even those are only averages. However, because the model makes strong predictions about seller behavior, these three observations - for each tester type - are sufficient to make crude inferences about three seller beliefs. In econometric terms, however, there are no additional degrees of freedom - so it is impossible to assess whether our estimates are statistically significant.

These results should also be interpreted very cautiously because three of the model's assumptions are suspiciously artificial. First, the model makes extremely strong assumptions about the buyer's and seller's knowledge: namely, that the buyer's and seller's per period bargaining cost $\left(c_{b}\right.$ and $c_{s}$ ), the discount rate $(r)$, the seller's

73. The inferential process is straightforward because the underlying parameters $\left(c_{s}, c_{b}\right.$, and $h$ ) can be expressed as algebraic functions of the seller's initial and final offer and the time spent bargaining $\left(p_{I}, p_{F}\right.$, and $\left.\Delta_{F}\right)$ :

$$
\begin{gathered}
c_{s}=\frac{r\left(p_{L} D_{F}-p_{F}\right)}{\left(1-D_{F}\right)}, \\
c_{b}=\frac{r D_{F}^{2}\left(p_{I}-p_{F}\right)}{\left(1-D_{F}\right)}, \\
\mathrm{h}=\frac{p_{l}\left(8+5 D_{F}-D_{F}^{2}\right)-p_{F}\left(5+2 D_{F}-D_{F}^{2}\right)}{3},
\end{gathered}
$$

where $D_{F}=\exp \left[-r \Delta_{F}\right]$. These explicit formulas are derived from Cramton, supra note 9; see also infra app. While these expressions seem algebraically formidable, they capture the strategic intentions of the model. For example, longer bargaining hours $\left(D_{F}\right)$ imply lower seller costs $\left(c_{s}\right)$ because sellers with lower costs would be willing to haggle longer. This is captured algebraically in equation (3) because

$$
\frac{d c_{s}}{d D_{F}}=\frac{r\left(p_{I}-p_{F}\right)}{\left(1-D_{F}\right)^{2}}>0
$$


Table II: Parameterization of the Bargaining Model BY TESTER TYPE ${ }^{a}$

White White Black Black Males Females Females Males

A. DATA ON SELLER CONCESSIONS

Number of Observations

Average Initial Price, $P_{1}$

Average Final Price, $\mathbf{P}_{\mathbf{F}}$

Average Time (in hours) Spent Bargaining, $\Delta_{F}$

$\begin{array}{rrrr}198 & 63 & 81 & 53 \\ 1076.9 & 1145.9 & 1360.8 & 1709.6 \\ 687.8 & 740.0 & 951.2 & 1468.1 \\ 0.60 & 0.77 & 0.59 & 0.66\end{array}$

B. ESTIMATED VALUE OF UNDERLYING PARAMETERS (holding $r$ constant) ${ }^{b}$

\begin{tabular}{lrrrr} 
Seller's bargaining cost (per hour), $c_{s}$ & 560.5 & 433.1 & 578.8 & 207.2 \\
Buyer's bargaining cost (per hour), $c_{b}$ & 592.6 & 469.5 & 635.4 & 331.4 \\
Buyer type's maximum valuation, $h$ & 2868.8 & 3017.9 & 3462.4 & 3792.7 \\
\hline
\end{tabular}

C. ESTIMATED VALUE OF UNDERLYING PARAMETERS (holding $c_{3}$ constant) ${ }^{\mathrm{c}}$
Discount rate (per hour), $T$
0.63
$0.46 \quad 0.52$
0.17
Buyer's bargaining cost (per hour), $c_{b}$
$\begin{array}{rrrr}365.5 & 308.7 & 437.0 & 309.8\end{array}$
Buyer type's maximum valuation, $h$

$\begin{array}{llll}2580.0 & 2750.6 & 3172.5 & 3722.3\end{array}$

\footnotetext{
a For tests that ended in refusal to bargain only.

b Calculated by evaluating the function for each individual and averaging the results across all individuals. Assumes that the discount rate is 0.1 per hour for all tester types.

c Calculated by evaluating the function for each individual and averaging the results across all individuals. Assumes that the discount rate is set so that the seller's cost is equal to $\$ 100$ per hour for all tester types.
}

reservation price $(\$ 0)$ and the distribution of buyer reservation prices (uniformly distributed between 0 and $h$ ) are all common knowledge. ${ }^{74}$ This assumption would fail, for example, if buyers did not know sellers' per period cost of negotiation. Common knowledge assumptions, however, are often used to solve bargaining games of this type. ${ }^{75}$

Second, the model's assumption that buyer reservation prices are uniformly distributed is highly restrictive. For example, if reservation prices followed a normal - bell-curve - distribution, profit-maximizing sellers would need to make more complicated inferences about both the mean and variance of reservation prices. ${ }^{76}$

74. This implies not only that the seller and buyer each knows these values, but that each knows that the other knows, and each knows that the other knows that the other knows, ad infinitum. See John Geanakoplos, Common Knowledge, J. Econ. Persp., Fall 1992, at 53.

75. See, e.g., Cramton, supra note 9. But see Robert H. Gertner \& Geoffrey P. Miller, Settlement Escrows, 25 J. LEGAL STuD. 87 (1995) (employing an asymmetric information bargaining model to settlement negotiations).

76. See supra text accompanying note 69 . As a theoretical matter, the sticker prices on the cars could limit the maximum amount that dealers could use for their initial offer and add another determinant of dealer behavior. But because the average dealer offer was substantially below the average sticker price even for black male testers, sticker prices probably were not a binding constraint. 
Our use of only three pieces of seller information, however, limits our ability to identify the parameters of other, more complicated, distributions. ${ }^{77}$

Third, the model assumes that the buyer and the seller discount their future gains from trade at the same rate. ${ }^{78}$ This assumption is suspect because buyers and sellers may have different discount rates. Moreover, as we explore below, ${ }^{79}$ it is possible that the seller has different discount rates for particular tester types. Without placing some restriction on the relative values of the discount rate, however, our information about the seller concession curve cannot identify the other underlying parameters.

Because of the nonstatistical estimation procedure and the model's restrictive assumptions, the estimates of the underlying parameters, contained in Table II and Figures 2-4, cannot be reliably interpreted as unbiased estimates of, for example, the seller's actual dollar cost of bargaining per hour. The parameter estimates, however, may provide some evidence to rank ordinally the sellers' beliefs about different tester types. Ordinal rankings are still useful in assessing the causes of the discrimination because knowing that sellers have lower costs of bargaining with black men, for example, an ordinal ranking of sellers' bargaining costs can help identify the presence of consequential animus.

Even these ordinal inferences, however, may be fraught with error. The results should be viewed cautiously as a first heuristic step, but along with ancillary data - reported below - they provide some insights into why sellers discriminate.

\section{Animus-Based Discrimination}

Figure 2 suggests that sellers have lower per-period costs of negotiating with black males than with any other tester type. For example, Table II shows that at a discount rate of $10 \%$ per hour sellers act as if their cost is $\$ 560$ per hour when bargaining with white males but only $\$ 207$ when bargaining with black males. Figure 2 shows that except when bargaining with black males, the seller bargaining costs with other tester types are relatively simi-

77. Three observations about the sellers' concession curve cannot be used to identify four underlying parameters: as in trying, for example, to infer both the mean and variance of the buyer reservation price distribution as well as the buyer and seller per-period cost.

78. Part B of Table II assumes a discount rate of $10 \%$ per hour while Figures $2-4$ shows the values of $c_{s}, c_{b}$, and $h$ for various discount rate values. These discount rates are substantially higher than the pure time value of money, but may be reasonable because they also include the risk that the bargaining could end at any time. See supra note 46.

79. See infra note 102 and accompanying text. 
lar. ${ }^{80}$ The sellers' bargaining costs with black males are estimated to be low because sellers made the smallest concessions to and spent the longest time bargaining with black male testers. The model predicts that higher bargaining costs would have led sellers to make quicker and more substantial concessions. ${ }^{81}$

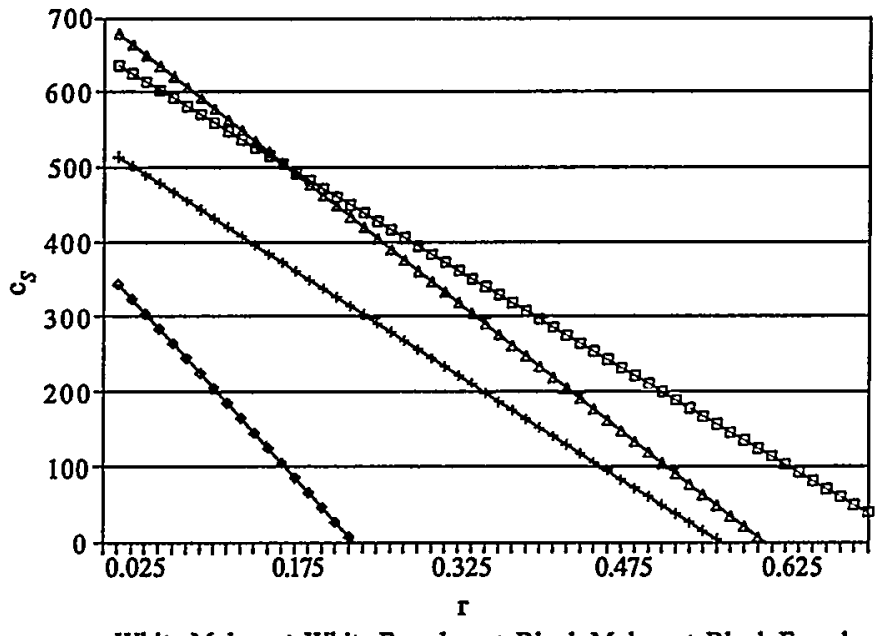

Figure 2: Estimates of Sellers' Per-Period Cost $\left(c_{s}\right)$ of Negotiating With Different Tester Race-Gender TyPes for VARying Discount Rates (r)

These results are inconsistent with associational animus as the cause of discrimination because the sellers are acting as if the cost of associating with white males was highest or second highest among all tester types. These estimates of $c_{s}$ are, however, consistent with the theory that "consequential animus" is at least partially responsible for the higher prices offered to black males. As discussed above, disproportionately valuing profits extracted from black males would lead dealers to act as if they had lower "net" costs of negotiation: sellers would hold out longer and make smaller concessions. Indeed, the sellers' slow and small concessions to black males are consistent with the hypothesis that sellers en-

80. Sellers act as if their cost of bargaining with white females might also be lower. See infra fig. 2.

81. In our larger sample, salespersons spent nearly $13 \%$ longer negotiating with the "minority" testers than with the white males, which casts doubt on salesperson animus as the source of price differences. The average test by a white male lasted 36.2 minutes. The average for the other testers was 40.8 minutes. A t-test reveals that these differences are statistically significant at the 0.001 level. 
joyed extracting dollars from black males twice as much as extracting dollars from white males. ${ }^{82}$

These estimates of seller bargaining cost provide some evidence of consequential animus, but without more data they cannot identify precisely whose animus influences the seller's behavior. Gary Becker has shown that a firm's behavior in the marketplace can reflect the animus of owners, employees, or consumers. 83 To explore the source of animus - especially the consequential animus that would produce higher offers for black males - we estimated regressions designed to reveal whether the race of a dealership's owner, salesperson, or customers influenced the amount of discrimination. If we assume that black market participants are less likely to have animus against other blacks, ${ }^{84}$ then by comparing the effect of, say, the salesperson's race on the amount of discrimination we may be able to isolate the source of the animus. The results of these regressions are reported in Table III.

\section{Owner Animus}

Table III includes a dummy variable MINOWN for minorityowned dealerships as well as an interaction dummy equalling one when both the tester and the owner were black. None of these had coefficients that were significant in any of the regressions, indicating that the owner's race did not influence the bargaining outcome and that black testers did not fare better at black owned dealerships. 85

There is additional evidence against the importance of owner animus in explaining discrimination. Bigoted owners should be

82. As shown in the Appendix, if sellers value black male profits $\alpha$ times more than white male profits, they will act as if their cost of bargaining is $c_{b m}=c_{w m} / \alpha$ (where $c_{b m}$ and $c_{w m}$ are the sellers cost of bargaining with black males and white males respectively). The estimates for $c_{b m}$ and $c_{w m}$ in Table II can be used to calculate an estimate for $\alpha$ equalling 2.7 (in other words, 560.46/206.16).

83. BECKER, supra note 57.

84. For a variety of social reasons, African-Americans may also act as if they harbor associational or consequential animus against other African-Americans. See Ayres, supra note 1 , at $840-41,847$.

85. We used as sources the "Black Pages," an analogue of the Yellow Pages in which firms that are more than $50 \%$ black-owned voluntarily list their businesses, supplemented by a City of Chicago listing of minority-owned businesses. Listing in either source is voluntary, so we may have excluded some black-owned dealerships. We were unable to find any female-owned dealerships in analogous sources. Because there were only 9 black-owned dealerships in our sample - these dealerships might have been able to "free-ride" on the market discrimination by charging their black customers a price that reflects the discriminatory premium at white-owned dealerships. It is also theoretically possible that black owners dislike dealing with blacks, but at a minimum this would implicate a nontraditional form of discrimination. 
Table III: Regressions of Initial and Final Profits and Markups on Control Variables, Race AND GeNDER DUMMIES, AND INTERACTION EFFECTS ${ }^{\mathrm{a}}$ ( $\mathrm{N}=404$; $\mathrm{t}$-statistics in parentheses)

\begin{tabular}{|c|c|c|c|c|}
\hline & $\begin{array}{l}\text { Initial } \\
\text { \$Profit }\end{array}$ & $\underset{\text { \$Profit }}{\text { Final }}$ & $\underset{\text { \%Markup }}{\text { Initial }}$ & $\begin{array}{c}\text { Final } \\
\% \text { Markup }\end{array}$ \\
\hline $\begin{array}{l}\text { TESTER RACE-GENDER DUMMIES } \\
\text { White Female } \\
\text { Black Male } \\
\text { Black Female }\end{array}$ & $\begin{array}{r}193.78 \\
(1.30) \\
886.18^{*} \\
(3.23) \\
399.67 \\
(1.60)\end{array}$ & $\begin{array}{r}225.44 \\
(1.76) \\
889.01^{*} \\
(3.82) \\
169.70 \\
(0.79)\end{array}$ & $\begin{array}{c}1.79 \\
(1.43) \\
6.72^{*} \\
(2.93) \\
3.06 \\
(1.47)\end{array}$ & $\begin{array}{c}2.02 * \\
(2.00) \\
7.06^{*} \\
(3.79) \\
0.98 \\
(0.58)\end{array}$ \\
\hline $\begin{array}{l}\text { NEIGHBORHOOD VARIABLES } \\
\text { Suburb (1=Suburb) } \\
\text { Suburb×Black Tester } \\
\text { Household Income } \times 10^{3} \\
\text { Percent Black in Neighborhood } \\
\text { Percent Black } \times \text { Black Tester }\end{array}$ & $\begin{array}{c}-230.04 \\
(-1.58) \\
63.64 \\
(0.25) \\
4.50 \\
(0.79) \\
-30.74 \\
(-0.12) \\
-916.89 \\
(-1.85)\end{array}$ & $\begin{array}{c}-221.91 \\
(-1.78) \\
263.76 \\
(1.22) \\
-0.08 \\
(-0.02) \\
117.92 \\
(0.54) \\
-540.93 \\
(-1.27)\end{array}$ & $\begin{array}{c}-1.64 \\
(-1.34) \\
0.95 \\
(0.45) \\
0.03 \\
(0.60) \\
-0.29 \\
(-0.14) \\
-7.30 \\
(-1.76)\end{array}$ & $\begin{array}{c}-1.51 \\
(-1.52) \\
2.61 \\
(1.53) \\
-0.001 \\
(-0.02) \\
0.88 \\
(0.51) \\
(-3.76) \\
(-1.12)\end{array}$ \\
\hline $\begin{array}{l}\text { OTHER CONTROLS } \\
\text { Tester Experience } \\
\text { Split } \\
\text { First }\end{array}$ & $\begin{array}{r}7.05 \\
(0.95) \\
-253.10 \\
(1.58) \\
50.82 \\
(0.52)\end{array}$ & $\begin{array}{r}5.95 \\
(0.95) \\
-252.93 \\
(-1.83) \\
127.96 \\
(1.52)\end{array}$ & $\begin{array}{c}0.05 \\
(0.83) \\
-1.71 \\
(-1.28) \\
0.17 \\
(0.20)\end{array}$ & $\begin{array}{c}0.04 \\
(0.80) \\
-1.37 \\
(1.25) \\
1.11 \\
(1.65)\end{array}$ \\
\hline $\begin{array}{l}\text { SELLER AND INTERACTION EFFECTS } \\
\text { Minority Owner (1=Yes) } \\
\text { Minority Owner×Black Tester } \\
\text { Tester WF, Seller WF } \\
\text { Tester WF, Seller BM } \\
\text { Tester BM, Seller WF } \\
\text { Tester BM, Seller BM } \\
\text { Tester BF, Seller WF } \\
\text { Tester BF, Seller BM }\end{array}$ & $\begin{array}{c}446.74 \\
(1.00) \\
-165.10 \\
(-0.28) \\
-69.39 \\
(-0.15) \\
76.56 \\
(0.26) \\
427.90 \\
(1.06) \\
379.60 \\
(0.95) \\
190.31 \\
(0.59) \\
464.32 \\
(1.42)\end{array}$ & $\begin{array}{c}472.22 \\
(1.24) \\
12.05 \\
(-0.02) \\
368.58 \\
(0.94) \\
-129.69 \\
(-0.51) \\
243.44 \\
(0.71) \\
80.02 \\
(0.23) \\
248.60 \\
(0.91) \\
673.29 * \\
(2.41)\end{array}$ & $\begin{array}{c}2.89 \\
(0.78) \\
-0.17 \\
(-0.03) \\
-0.89 \\
(-0.23) \\
0.19 \\
(0.08) \\
4.13 \\
(1.22) \\
3.41 \\
(1.02) \\
2.02 \\
(0.75) \\
3.30 \\
(1.21)\end{array}$ & $\begin{array}{c}3.53 \\
(1.18) \\
0.70 \\
(0.18) \\
2.18 \\
(0.70) \\
-1.22 \\
(-0.61) \\
2.58 \\
(0.94) \\
0.92 \\
(0.34) \\
2.46 \\
(1.13) \\
5.54 * \\
(2.50)\end{array}$ \\
\hline $\begin{array}{l}\text { SUMMARY STATISTICS } \\
\text { ADJ-R } \\
\text { SSR } \times 10^{3}\end{array}$ & $\begin{array}{c}0.26 \\
256859\end{array}$ & $\begin{array}{c}0.33 \\
187741\end{array}$ & $\begin{array}{r}0.29 \\
17.96\end{array}$ & $\begin{array}{r}0.39 \\
11.78\end{array}$ \\
\hline $\begin{array}{l}\text { F-TESTS } \\
\text { White Female Tester Effect } F(3,367) \\
\text { Black Male Tester Effect } F(6,367) \\
\text { Black Female Tester Effect } F(6,367)\end{array}$ & $\begin{array}{l}0.78 \\
8.07 * \\
2.99 *\end{array}$ & $\begin{array}{r}1.66 \\
14.72 * \\
4.12^{*}\end{array}$ & $\begin{array}{l}0.83 \\
7.77^{*} \\
3.06^{*}\end{array}$ & $\begin{array}{c}1.79 \\
16.64 * \\
4.62^{*}\end{array}$ \\
\hline
\end{tabular}

* Significantly different from zero at the 5 percent level.

a Other variables included in regression but not shown to save space: constant term, model dummies, TIME, day-of-week dummies, and week-of-month dummies. See supra Table I. 
more likely to discriminate against their own employees, with whom they presumably have to associate quite closely over an extended period of time, than against their customers. Given that owners frequently hire nonwhite male salespersons, who comprised $21.3 \%$ of the salespeople in our sample, it seems implausible that these owners would need a $\$ 500$ higher markup to compensate them for selling to nonwhite male customers.

\section{Salesperson Animus}

Salespeople are another possible source of animus. The interaction effects in the regressions of Table III attempt to test whether the gender and race of the salesperson influenced the amount of discrimination our testers experienced. The coefficients were uniformly insignificant, casting doubt on both consequential and associational employee animus as a source of discrimination. Black testers did no worse when buying from white salespersons, and women did not get worse deals when the salesperson was male. ${ }^{86}$

We did find some direct evidence of animus in the form of explicitly racist or sexist statements by salespeople. However, salespeople were more likely to use hostile language when bargaining with white males than with other testers. ${ }^{87}$

\section{Customer Animus}

A dealership's customers should also be considered as a potential source of associational animus against black or women consumers. John Yinger, for example, concludes that in the housing market, discrimination against blacks is motivated by realtors' perceptions that other renters or house buyers dislike having a black neighbor. ${ }^{88}$ Sellers' effective per period cost, $c_{s}$ could be higher for black or female consumers if their presence in the showroom made it less likely that others, whites or men, would shop there.

The evidence for associational animus on the part of customers, however, is weak. Concerns about the reactions of other customers

86. The one exception was that black women did seem to get worse deals when buying from black salesmen. $F$ tests for the joint significance of the tester-seiler interactions were also uniformly insignificant, with the exception of black females in the final markup equation.

The original study found that women and blacks received higher offers when negotiating against a salesperson of the same race-gender, and that testers were steered toward salespeople of the same race and gender as themselves. Ayres, supra note 1 , at 819,840 . We detected, however, no evidence of such steering in the current study.

87. Salespeople made hostile or demeaning statements in about $4 \%$ of the white male tests and in just under $3 \%$ of the nonwhite male tests.

88. Yinger, supra note 14. 
should lead dealers to shepherd blacks and women out of the showroom as rapidly as possible to avoid their being seen by other potential customers. Yet it was white male testers, rather than blacks or white women, who had the shortest average negotiating sessions.

There is, however, some evidence of neighborhood-based consequential animus. Black testers buying in a predominantly white neighborhood might encounter more customer-based consequential animus than in a black neighborhood. Under this theory, black customers might receive lower offers in black neighborhoods because sellers would be less likely to reflect the consequential animus of their customers. Table III estimates that black testers did receive lower final offers when shopping in black, rather than white, neighborhoods. The coefficients on these interaction variables were large, in the range of $-\$ 540$ to $-\$ 900$, but were statistically insignificant. ${ }^{89}$

\section{E. Cost-Based Statistical Discrimination}

Differences in buyers' cost of bargaining $\left(c_{b}\right)$ might also induce seller discrimination. One group of buyers might have high bargaining costs relative to another either because of their opportunity costs, for example lost wages are high, or because they have a greater dislike for the process of bargaining. ${ }^{90}$ The key question in the present context is whether these bargaining costs are correlated with race or gender.

Figure 3 depicts our estimates of the buyers' costs of bargaining for each buyer type. For all discount rates, the ordering of buyers' transaction costs remains stable: black males have the lowest costs

89. Neighborhoods are defined by what the City of Chicago calls "Community Areas." Each contains 30,000-60,000 people. "Community areas are defined by the City of Chicago as groups of census tracts. They were first identified in the 1930s by the Social Science Research Council of the University of Chicago. They correspond roughly to informally recognized neighborhoods such as Lakeview and Hyde Park. The boundaries have changed very little since their inception ...." Crty of Chicago, Chicago Statistical Abstract (1992).

Although the signs of the coefficients are consistent with consequential animus, there are compelling theoretical reasons to exclude consequential animus by consumers as a cause of disparate treatment by dealers. Most consumers do not have information about the prices other consumers have received, so they are not in a position to take pleasure in others' misfortune, which is the definition of consequential animus.

90. The social psychology literature has not reached a firm conclusion about whether there are racial or gender differences in aversion to bargaining. JEFFREY $Z$. RUBIN AND Bert R. Brown, The Social Psychology of Bargainina and Negotiation 162-65, 169-74 (1975). A recent newspaper article interviewed dealers who suggested that middleclass black males associated the need to bargain with poverty and were thus reluctant to bargain. Warren Brown, Who Gets the Best Deals on Wheels? WASH. Post, Dec. 14, 1990, at F1. 
and black females have the highest. See Table II for calculations at a representative discount rate.

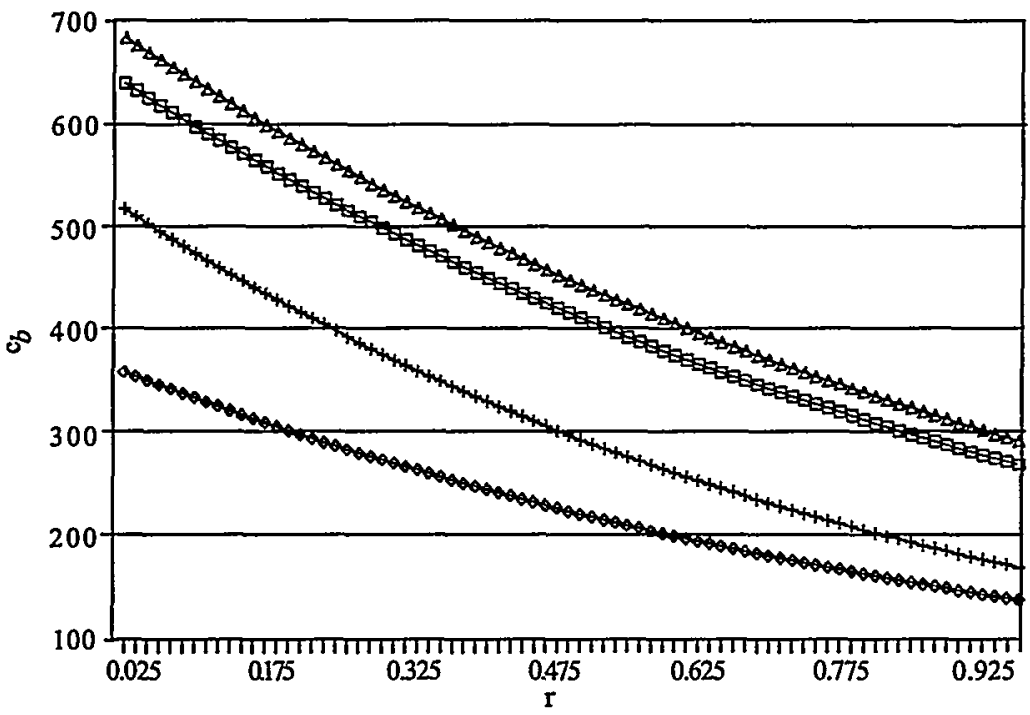

口 White Male + White Female $\diamond$ Black Male $\Delta$ Black Female

Figure 3: Estimates of the Per-Period Cost of

Negotiating for Different Tester Race-Gender Types $\left(c_{b}\right)$ FOR VARYING DISCOUNT RATES ( $r$ )

Figure 3 thus provides some evidence that the race and gender discrimination was caused by the sellers' perceptions of differences in buyers' bargaining costs. The higher offers to black female testers might be partially attributable to their higher costs of bargaining. White female and black male testers also had lower estimated bargaining costs $\left(c_{b}\right)$ than white male buyers which would by themselves have produced lower offers. But our parameter estimates tell us that despite their own lower bargaining costs, white females and black males also faced lower seller bargaining costs as well as less favorable distributions of reservation prices. On balance, the seller bargaining costs and reservation price effects dominated.91

91. Ancillary evidence suggests that dealers may have attempted to take advantage of women's and blacks' greater aversion to bargaining by making it procedurally harder for these buyer types to purchase a car. First, black males were more often asked to sign purchase orders ( $40.2 \%$ vs. $27.6 \%$ for white males; $\chi^{2}(1)=7.14$ ) and to put down a deposit $\left(37.7 \%\right.$ vs. $25.6 \%$ for white males; $\left.\chi^{2}(1)=6.78\right)$. Black testers were also much more likely than white males to be "bumped" - that is, to have the manager raise a salesperson's offer $(7.0 \%$ vs. $\left.1.5 \% ; \chi^{2}(1)=7.66\right)$. 


\section{F. Revenue-Based Statistical Discrimination}

Figure 4 estimates sellers' beliefs about tester reservation prices, particularly the implied highest-valuing buyer for each of the different buyer types. ${ }^{22}$ For all discount rates, there is a stable ordering of reservation prices that matches the ordering of initial and final seller offers: sellers believe that black males are willing to pay the most, and white males to pay the least.

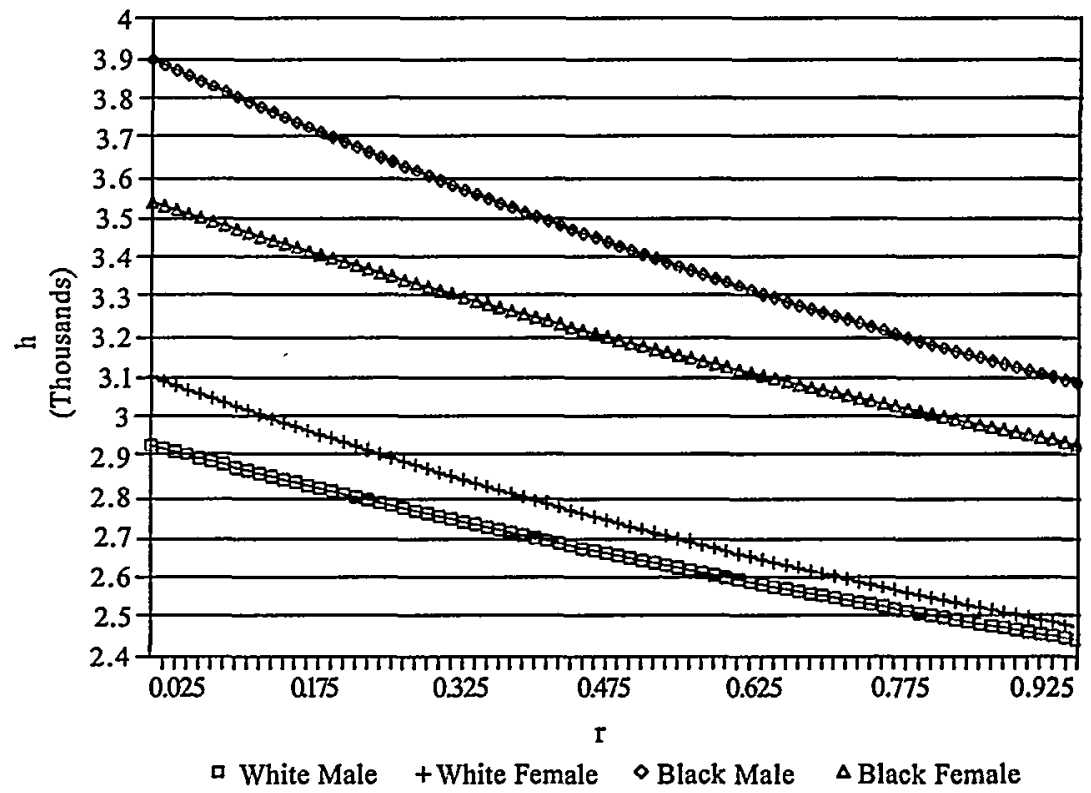

Figure 4: Estimates of Reservation Price (h) For

Different Tester Race-Gender Types for VARYING Discount RATEs (r)

The plausibility of revenue-based statistical discrimination as an explanation for the discrimination we found is heightened by the fact that salespersons have their own term for a kind of statistical discrimination, which they call "qualifying the buyer." "Qualifying" is the process of estimating how much the buyer is willing andor able to pay on the basis of direct observations, such as how the buyer is dressed and what kind of car she is currently driving, and answers to questions the seller asks, "How did you get to the dealership?" and "Have you visited other dealerships?" Even though

92. That is, the figure depicts implicit seller beliefs about the upper bound $\left(h_{i}\right)$ of buyer reservation prices for each buyer type. Because sellers' behavior does not depend on the other characteristics of the uniform distribution (such as the mean or the lower bound), it is not possible to estimate these parameters using test buyers. 
the average black person is poorer than the average white male, the upper tail of the valuation distribution for blacks could be higher or fatter because of differences in information or higher costs of search.

\section{Search Costs}

Sellers might perceive that race and gender are related to buyers' search costs for several reasons. For example, black consumers might have higher search costs because they are less likely than whites to own a car at the time they are shopping for a new one, and therefore might have more difficulty travelling to multiple dealerships.93

Our data provide some evidence that sellers considered search costs to be differentially important for different groups of testers. Nonwhite male testers were more than 2.5 times as likely as white males to be asked how they got to the dealership, suggesting that dealers show particular interest in determining whether nonwhite males have substantial opportunities to search. In addition, testers who revealed that they did not own a car had to pay $\$ 127$ higher markup while those who indicated that they had visited other dealerships saved $\$ 122$ although these results were only significant at a 20 percent level. ${ }^{94}$

The evidence does not uniformly support a search cost explanation, however. If sellers are sensitive to buyers' search costs in setting prices, we would expect black testers to receive better deals in the suburbs than at urban dealerships. By travelling the substantial distance from the center city to the Chicago suburbs, where very few blacks live, blacks are in effect signalling to suburban dealers that they are willing and able to undertake an extensive search for a

93. Fred Mannering \& Clifford Winston, Brand Loyalty and the Decline of the American Automobile Firms, Brookings PAPERS ON ECON. ACTTVITY - MrCROECONOMICs 67 (1991). There is a large, uneven, and largely dated marketing literature that does seem to support the notion that "[v]ariation in prepurchase search behavior is related to racial differences." See, e.g., Carl E. Block, Prepurchase Search Behavior of Low-Income Households, 48 J. RetaILING, Spring 1972, at 3,9. Laurence Feldman and Alvin Starr also conclude that there are differences in search behavior by race although they find that these diminish after controlling for income. Laurence Feldman \& Alvin Starr, Racial Factors in Shopping Behavior, in A New Measure of ResponsibirtTy for Marketing 216 (Keith Cox \& Ben M. Enis eds., 1968). For a survey of studies examining differences in car ownership rates by race that concludes that blacks are less likely to own a car than whites, even after controlling for income, see Raymond A. BAuER \& SCOTt M. CunNINGHaM, Studies IN tHE Negro MarKET 156-78 (1970).

94. These figures were derived by constructing dummy variables for the tests where this information was revealed and including them in the final profit regression in Table I. Testers revealed this information only when asked, however, and the dealer's decision to ask the question might not be exogenous to the dealer's final offer. 
car. Yet contrary to this theory, the regression estimates that blacks negotiating in suburbs faced initial and final offers that were respectively $\$ 64$ and $\$ 264$ higher than offers given to blacks at city dealerships - these differences are statistically insignificant. ${ }^{95}$ Moreover, initial and final offers for black testers in all-white neighborhoods were $\$ 916$ and $\$ 540$ higher than in all-black neighborhoods; again, this result was statistically insignificant.96 The presence of black customers in white neighborhoods did not signal a willingness to search that translated into lower dealer offers. ${ }^{97}$

\section{Consumer Information}

Race and-or gender may also be correlated with buyers' information about the car market. For example, a Consumer Federation of America survey found that $37 \%$ of respondents did not believe that the sticker price on a car was negotiable. ${ }^{98}$ More important for our purpose is the fact that there were wide differences in consumer knowledge by race and gender. Sixty-one percent of blacks surveyed believed the price was not negotiable while only $31 \%$ of whites believed this. Women were more likely than men to be misinformed about the willingness of dealers to bargain, although the disparities were not as great as between blacks and whites. ${ }^{99}$

Sellers in our study may have been motivated in part by such informational disparities in quoting higher prices to blacks and women. Dealers were somewhat more likely to volunteer information about the cost of the car to white males than to the other testers, possibly because they believed that white males already had

95. The t-statistics for these coefficients were .25 and 1.22 respectively.

96. The t-statistics were only 1.85 and 1.28 .

97. Customer animus and search-cost theories of discrimination may not be independent. Neighborhoods with few black residents probably also have stronger animus against black customers, and it is precisely by venturing into such hostile neighborhoods that blacks could most effectively signal that they have low search costs. Thus, animus might swamp, or at least confound, the signalling effect and cause blacks bargaining in such neighborhoods to pay higher prices.

98. Consumer Fedn. of Am., U.S. Consumer Knowledge: The Results of a NaTIONWIDE TEST (1990); see also Ayres, supra note 1, at 856 n.115.

99. See Consumer FedN. OF AM., supra note 98, at 8; see also Ayres, supra note 1, at 856 n.115. Because the survey respondents were not limited to people who were actually interested in buying a car, the survey may overstate racial differences in information among the car buying public if nonbuying blacks are relatively less informed than nonbuying whites. George Moschis and Roy Moore do find "differences in consumer knowledge, skills and attitudes between blacks and whites" controlling actual purchase behavior. George Moschis \& Roy Moore, Racial and Socioeconomic Influences on Adolescent Consumer Behavior, in Proceedings of the American Marketing Association 261 (1981). 
such information. ${ }^{100}$ More significantly, dealers used the sticker price as their first offer to $29 \%$ of nonwhite males, but to only $9 \%$ of white male testers. ${ }^{101}$ This suggests that sellers believed white males were more knowledgeable than other testers about the possibility of departing from sticker prices.

In sum, this exercise of estimating the causes of discrimination has shown that the sellers' bargaining behavior is broadly consistent with revenue-based statistical inference as a partial cause of the sellers' discrimination: sellers' differential beliefs about the testers' reservation prices track sellers' initial and final offers. This exercise has also shown that sellers may discriminate against different buyer types for different reasons. Figure 3 shows that sellers' discrimination against black females may in part stem from a belief that black females are more averse to bargaining than white males, and Figure 2 suggests that consequential animus may explain part of sellers' discrimination against black males.

We emphasize again that these results must be interpreted cautiously. In order to identify the relationship between the sellers' concessions and the underlying parameters, we have had to make strong assumptions. Under alternative assumptions, the concession data are susceptible to alternative interpretations. For example, instead of assuming that the discount rate is the same for each buyer type, we might assume a constant seller bargaining cost for the four kinds of testers, and allow the discount rate to vary. Part $\mathrm{C}$ of Table II shows that when we assume a constant seller bargaining cost of $\$ 100$ per hour, the implicit discount rate for negotiations with black male testers is substantially lower than the discount rate for white males - .17 vs. $.63 \% .{ }^{102}$ Even assuming a constant seller bargaining cost, the model's estimates of reservation prices and buyer cost retain the same ordinal ranking - suggesting that our conclusions about statistical discrimination are robust to this alternative assumption.

100. White males were given unsolicited cost information in $55 \%$ of their tests while all other testers were given such information in $48 \%$ of tests. The difference was not statistically significant at the 5 percent level, however.

101. This difference was statistically significant $\left(\chi_{(1)}^{2}=25.9\right)$.

102. Because the discount rate can be thought of as the probability that bargaining will exogenously terminate, this might be interpreted to mean that black males have a considerably lower probability of exogenous termination than the other tester types. Under this interpretation, dealers would be willing to hold out longer for a high price with black males because the dealers believe there is a low chance the bargaining will be terminated. 


\section{ConClusion}

The audits analyzed in this article further demonstrate a strong dealer tendency to offer white male testers lower prices than black testers. The task of combatting this disparate treatment may be particularly difficult because that discrimination may have diverse causes. While enhanced enforcement of section 1981's ${ }^{103}$ prohibitions against disparate racial treatment is a laudable goal, I continue to be pessimistic that private litigation will be sufficient to deter discrimination. This conclusion suggests instead that encouraging "no-haggle" selling might reduce dealers' discretion to discriminate.

In the three years since the original discrimination study was published, the retail car market has seen a dramatic shift away from haggling. ${ }^{104}$ More than $10 \%$ of new car dealers currently sell all of their cars at nonnegotiable prices, and more than $70 \%$ of dealers sell at least one of their models without dickering. ${ }^{105}$ There has also been a dramatic growth in the use of third-party buying services that bargain on behalf of individual consumers - with more than one-quarter of dealerships selling cars through such services. ${ }^{106}$

Many newspaper articles have linked this shift away from haggling to a growing frustration of women and minorities with the process and results of negotiation. ${ }^{107}$. Indeed, the original study

103. 42 U.S.C. $\S 1981$ (1988), amended by 42 U.S.C. § 1981 (Supp. V 1993).

104. Hal Porter, One Price Fits All; No-Haggle Car Deals Are Finding a Niche, ThE RECORD, June 17, 1993, available in LEXIS, News Library, NJREC File.

105. See, e.g., James Bennet, Buying Without Haggling As Cars Get Fixed Prices, N.Y. TIMES, Feb. 1, 1994, at A1. Satum has been successful in prohibiting its dealers from haggling over the sticker price of its cars. In many cities, so called "no dicker" or "one price" dealerships have also independently decided to forego the potential profits of negotiation. The practice is especially prevalent among high-volume sellers: "Fifteen percent of highvolume operators today have at least a single one price dealership." Mary Connelly, 'Oneprice' growth tapers off, Automotive NEws, Dec. 27, 1993, at 1 (citing a December 1993 J.D. Powers and Associates study).

106. For example, a nonprofit corporation, Car Bargains (for a fee of \$135) solicits offers from at least five dealers in the customer's area. Your Money: Services Can Save Thousands with No-Haggle Car Buying, (CNN television broadcast, July 23, 1994), available in LEXIS; Nexis Library, SCRIPT File.

107. Ann Arnott, The Wise Buyer's Car Guide, EssENCE, Nov. 1993, at 119, 120 ("If you're a sister who hates to bargain, try shopping for a car at a 'one-price' or 'no-haggle' dealership."); Tim Martin, Thousands Due For Saturn Homecoming, GANNETT NEws SERVICE, June 23, 1994, available in LEXIS, News Library, GNS File ("[Saturn's] low-pressure approach appeals especially to women ...."); John M. McGuire, Women Fuel Demand For Sport Utility Vehicles, St. LouIs Post-DisPATCH, May 30, 1993, available in LEXIS, News Library, SLPD File ("That's why Saturn has the one-price deal. Women don't like the car-lot haggle."); Bob Storck, American Classics: Trucks With an Attitude, WASH. TrMEs, Dec. 24, 1993, available in LEXIS, News Library, WTIMES File ("[T]he dealership experience is often demeaning to women. It [is] suggested the one-price, no haggle concept pioneered by Satum and Ford Escort should have appeal."); Car Buying Could Be Fairer Without the Hag- 
may have played a small role in heightening consumer awareness, particularly about the extent of price discrimination: the article was widely reported in the news media, ${ }^{108}$ and several writers have referred to its finding as an explicit reason why women or minorities might want to buy from no-haggle dealerships or through thirdparty buying services. ${ }^{109}$ Many dealers themselves have responded by claiming that they, unlike others in the industry, treat women fairly. ${ }^{110}$ A few dealers' advertisements have even attempted to distinguish explicitly their practices from the conduct uncovered in the original study. ${ }^{111}$

The experience of the last three years suggests that the institution of haggling may not be immutably entrenched. Minor legal changes that improve consumer information may be sufficient to move the market. In particular, the Federal Trade Commission could more clearly define nonfraudulent uses of the "dealer invoice" amount, so that no-haggle dealerships could speak more credibly about their gross profit. ${ }^{112}$ Or, as argued in the original article:

gling Hassle, BuFf, NEws, Feb. 13, 1994, available in LEXIS, News Library, BUFNEW File ("No-haggle pricing could prove a particular hit with the greater number of women who buy cars these days, since so many feel ill at ease in the auto world.").

108. Brown, supra note 90, at F1; Dennis Cauchon, Undercover tests identify bias, USA TODAY, Sept. 26, 1991, available in LEXIS, News Library, USATDY File; Ellen Goodman, Driving home a point about not being a victim, CHI. TRIB., Dec. 30, 1990, at § 5, 1; Delores Kong, Study Offers Proof of Car-Sales Bias, Boston Globe, Feb. 14, 1993, at 36; Joann Muller, Study finds race bias in car prices, DET. FreE PRESs, Dec. 14, 1990, at 1A; William E. Schmidt, White Men Get Better Deals on Cars, Study Finds, N.Y. Tnmes, Dec. 13, 1990, at A6; Blacks, Women Charged More for Cars, Study Says, L.A. Tmes, Dec. 14, 1990, at D4.

In addition to newspapers, the study was also widely discussed on television and radio shows including the ABC Evening News, the CBS Morning Show, CNN, Oprah, three PrimeTime Live segments, and NPR's All Things Considered.

109. See, e.g., Amott, supra note 107, at 120; Will Astor, No-dicker deals, RocHEsTER Bus. J., Oct. 1, 1993, available in LEXIS, News Library, ROCH File; Shelly Donald Collidge, Purchasing a Car? Using a Buying Service Could Save Big Bucks, ChRISTIAN ScI. MONITOR, Sept. 8, 1994, at 8 ("A 1991 Harvard Law Review study found women and minorities pay prices that give a dealer up to 242 percent more profit than the dealer would get on sales to white males. Because a club buyer negotiates, the dealer doesn't know who the customer is."); Kim Ode, Women pay price for capitalism, STAR TRIB. (MINNEAPOLIS), May 25, 1993, at $1 \mathrm{E}$.

110. See, e.g., Advertisement for Silver Lake Dodge \& Leasing, Boston WoMAN, Winter 1990 , at 7a ("Where you don't have to bring a man along to be treated like a customer."). But a PrimeTime Live audit of one of Marge Schotz's dealerships in Cincinnati uncovered discrimination against a female tester - even though Schotz explicitly advertises that she treats women fairly. PrimeTime Live (May 24, 1993).

111. See, e.g., Mass Mailing From Gerald Lincoln-Mercury, Skokie, IL (Nov. 8, 1993) ("[A] recent Harvard University research project document[s that] ... [s]ome groups paid over three times the amount of dealer mark-up than others were able to negotiate. ... We believe that no one should have to pay more because of race, gender or negotiation skills.").

112. The regulation defining the "dealer invoice" amount should exclude from the "dealer cost" or "dealer invoice" any rebates or kickbacks from the manufacturer to the dealer. See Ayres \& Miller, supra note 47, at 1062. 
Regulators might reduce the number of sales with disparately high markups by mandating various types of disclosure from dealers to consumers. Dealerships, for example, might be required to reveal the average price for which each make of car is sold. Knowing that the dealership is attempting to charge $\$ 3000$ more than the average price would allow high-markup consumers to protect themselves. ${ }^{113}$

Armed with this information, consumers could protect themselves by patronizing no-haggle dealerships. This type of mandated disclosure would reduce the dealers' opportunity to extract a large profit from a small group of consumers and thus eliminate the primary reasons that dealers like to haggle.

The time is particularly ripe to consider such reform because the industry may be on the verge of tipping almost completely to "nohaggle" sales - needing only a slight nudge from enlightened regulation. ${ }^{114}$ The current equilibrium with $10 \%$ of dealers using nohaggle approaches may not be stable. The presence of no-haggle dealers has provoked an "emotional response" from the other dealers, ${ }^{115}$ and the growth rate of no-haggle sales has begun to taper. ${ }^{116}$

Nudging the retail market toward no-haggle selling would advance both the equity and efficiency of car sales. ${ }^{117}$ The dealers' attempts to extract high profits from a small group of consumers creates large costs for both dealers and consumers. No-haggle sales require fewer sales people and fewer dealerships. There are good reasons for Chicago to have 94 movie theaters, but Chicago does not need 523 car dealerships. 118 The overhead at many of these dealerships and the salaries of many salespeople are paid for by a

113. Ayres, supra note 1, at 869 . Alternatively, regulators might force dealers to directly reveal the size of their markup. See Ayres \& Miller, supra note 47, at 1063-64.

114. Somewhat speculatively, I predict that if "no-haggle" sales reach $40 \%$ of a geographic market that substantially all of the dealers in that market would soon be forced to shift away from dickering on the new car prices. At some critical market share, the multiple no-haggle dealerships will start competing for consumers on the basis of the publicly admitted prices. It will be increasingly difficult for haggle dealerships to sell at prices above the nohaggle prices. Most current no-haggle dealerships do not have enough no-haggle competition to drift them to publicly compete on no-haggle prices.

115. Bennet, supra note 105; see also Tim Martin, No-Dicker Sticker Has Mixed Success, Nashunlle Tennessean, Apr. 12, 1994, at D6 ("The competition between one-price and traditional dealers has changed from a battle to an all-out war.' " (quoting Mike Rikess, a consultant for one-price dealerships)).

116. Connelly, supra note 105 .

117. In small towns, a shift to fixed-price competition might facilitate anticompetitive collusion because competitors could more easily learn when other dealers were chiseling on the collusive price. But a general move away from no-haggle bargaining might increase consumer choice in all but the most isolated towns. No-haggle sales would make it much easier to purchase a car over the phone or through the mail - so that small town residents could easily compare their local prices to prices quoted by big-city dealers.

118. These figures are taken from the Chicago area Yellow Pages. 
few consumers who pay disproportionately high markups. This is not only inefficient, but also unfair.

To be sure, shifting to no-haggle sales might not be a panacea, ${ }^{119}$ but more than efficiency is at stake. This article has further substantiated the possibility of systematic racial and gender discrimination in new car sales. Our tentative estimation of the bargaining model suggests that this discrimination has diverse causes. Instead of using traditional civil rights approaches to eliminate race and gender disparities within a larger system of haggling, it may be more appropriate to target haggling itself and the inequitable price dispersion that haggling induces. financing, and other ancillary terms of trade. 


\section{APPENDIX}

Cramton shows that the seller's equilibrium strategy can be characterized by a concession function indicating the offers $(p)$ that it would be willing to make (or counteroffers it would be willing to accept) for any given delay $(\Delta)$ :

$$
p(\Delta)=e^{-r_{\Delta}}\left(x b_{I}+\frac{\mathcal{C}_{s}}{r}\right)-\frac{c_{s}}{r},
$$

where $b_{I}$ is the buyer type that is indifferent about accepting the seller's initial offer, and $x$ equals the seller's share of the gains from trading with a buyer of type $b_{i}{ }^{120}$

$$
x=\frac{1}{2}+\frac{\left(c_{b}-c_{s}\right)}{2 r b_{I}} .
$$

$b_{I}$ is determined by the first-order condition that maximizes the seller's expected payoff. Assuming that buyers' reservation prices follow a uniform distribution on the interval $[0, h]$, this first order condition is:

$$
p_{I}=x b_{I}=\frac{3\left(h-b_{I}\right)}{2}-\frac{3\left(2 c_{b}\right)^{1 / 2}\left(c_{b} / 3-c_{s}\right)}{(2 r)^{3 / 2}\left(x b_{I}+c_{s} / r\right)^{1 / 2}}-\frac{c_{s}}{r}
$$

The buyers' participation constraint completes the model. Buyers whose reservation price is below some critical value, $b_{F}$, cannot profitably signal their type because the transaction costs of delay produce negative buyer payoffs. Anticipating that any gains from trade will more than be consumed in bargaining, these low-valuing buyers will refuse to participate in the game. Sellers can calculate the maximum delay, $\Delta_{F}$ (and associated $b_{F}$ ), after which a rational buyer would be unwilling to bargain:

$$
\Delta_{F}=-\frac{\ln \left[2 c_{b} /\left(r b_{I}+C\right)\right]}{2 r}
$$

where $C=c_{s}+c_{b}$. Buyer offers made after $\Delta_{F}$ thus represent out-ofequilibrium behavior (which occurred because our testers followed a bargaining script and were not subject to the same participation constraint). We assume that any seller receiving an offer after a delay greater than $\Delta_{F}$ would believe with probability one that the

120. See Cramton, supra note 9. The term "gains from trade" refers to the amount by which the buyer's value exceeds the seller's. The division of gains under symmetric information was first derived by Rubinstein and is often referred to as the buyer's and seller's Rubinstein share. Ariel Rubinstein, Perfect Equilibrium in a Bargaining Model, 50 ECONOMETRICA 97 (1982). 
buyer's reservation price is $b_{F}$. Sellers should therefore refuse to make further concessions once the delay reaches $\Delta_{F}$. The buyers' participation constraint can thus help explain the fact that sellers at times refused to make further concessions when negotiating with our testers.

Combining equations (2) and (3) with the facts that the initial price $p_{I}=p(\Delta=0)=x b_{I}$ and the final price $p_{F}=p\left(\Delta=\Delta_{F}\right)$, it is possible to solve for $c_{s} c_{b}$, and $h$ as functions of the observable variables and $r$ (as shown in equations (1)-(3), supra at note 73).

\section{Consequential Animus}

If a seller's payoff increased by a factor $\alpha>l$ for each additional dollar secured in negotiations with a disfavored consumer group, then $\mathrm{x}$ can be interpreted as a measure of consequential animus. If $x=2$ the seller gains twice the utility from extracting profits from a disfavored buyer. Increases in $x$ cause the seller to bargain as if its effective per period cost of bargaining was lower so that $c_{s}^{\prime}=c_{s} / \alpha$. Resolving for the Rubinstein shares, the expression for $x$ in equation (2) would become:

$x^{\prime}=(1 / 2)+\left(c_{b}-c_{s}^{\prime}\right) / 2 r b_{1}$.

An increase in consequential animus (in other words, a rise in $\alpha$ ) would thus be reflected in a lower $c^{\prime}{ }_{s}$ and a higher seller share of the gains from trade. 